\title{
Alginate: Current Use and Future Perspectives in Pharmaceutical and Biomedical Applications
}

\author{
Marta Szekalska, ${ }^{1}$ Agata Puciłowska, ${ }^{1}$ Emilia Szymańska, ${ }^{1}$ \\ Patrycja Ciosek, ${ }^{2}$ and Katarzyna Winnicka ${ }^{1}$ \\ ${ }^{1}$ Department of Pharmaceutical Technology, Medical University of Białystok, Mickiewicza 2c, 15-222 Białystok, Poland \\ ${ }^{2}$ Department of Microbioanalytics, Warsaw University of Technology, Noakowskiego 3, 00-664 Warsaw, Poland \\ Correspondence should be addressed to Marta Szekalska; marta.szekalska@umb.edu.pl
}

Received 26 September 2016; Revised 16 November 2016; Accepted 5 December 2016

Academic Editor: Muhammet U. Kahveci

Copyright (c) 2016 Marta Szekalska et al. This is an open access article distributed under the Creative Commons Attribution License, which permits unrestricted use, distribution, and reproduction in any medium, provided the original work is properly cited.

Over the last decades, alginates, natural multifunctional polymers, have increasingly drawn attention as attractive compounds in the biomedical and pharmaceutical fields due to their unique physicochemical properties and versatile biological activities. The focus of the paper is to describe biological and pharmacological activity of alginates and to discuss the present use and future possibilities of alginates as a tool in drug formulation. The recent technological advancements with using alginates, issues related to alginates suitability as matrix for three-dimensional tissue cultures, adjuvants of antibiotics, and antiviral agents in cell transplantation in diabetes or neurodegenerative diseases treatment, and an update on the antimicrobial and antiviral therapy of the alginate based drugs are also highlighted.

\section{Introduction}

Alginates (ALG) are a group of naturally occurring anionic polysaccharides derived from brown algae cell walls, including Macrocystis pyrifera, Laminaria hyperborea, Ascophyllum nodosum $[1,2]$, and several bacteria strains (Azotobacter, Pseudomonas) [3]. This term usually referred to alginic acid and its salts, but it can also be used for all derivatives of alginic acid. ALG are linear biopolymers consisting of 1,4-linked $\beta$-D-mannuronic acid (M) and 1,4 $\alpha$-L-guluronic acid (G) residues (Figure 1) arranged in homogenous (poly-G, poly$\mathrm{M}$ ) or heterogenous (MG) block-like patterns [1-4]. With regard to the initial source material, commercial ALG may differ in composition and the sequence of G- and M-blocks.

ALG extraction process from seaweeds is uncomplicated but multistage procedure, which usually starts with treating the dried raw material using diluted mineral acid. After further purification, the obtained alginic acid is converted into water-soluble sodium salt in the presence of calcium carbonate, which is next transformed back into acid or its expected salt (Figure 2) [2, 4].

Commercial ALG are exclusively possessed from algal sources, although alternative production by microbial fermentation has been recently explored in order to provide ALG with more defined physicochemical properties [3].

Among various ALG, sodium alginate is one of the most widely investigated ones in the pharmaceutical and biomedical field and its monograph is included into both the European Pharmacopeia and the United States Pharmacopeia $[5,6]$. The current pharmacopoeial requirements regarding sodium alginate are presented in Table 1 .

\section{General Properties of ALG}

Currently used ALG possess a high degree of physicochemical heterogeneity which influences their quality and determines potential applicability. ALG are commercially available in various grades of molecular weight, composition, and distribution pattern of M-block and G-block, the factors responsible for their physicochemical properties such as viscosity, sol/gel transition, and water-uptake ability. The molecular weight, expressed as an average of all the molecules present in the sample, of commercial ALG varies between 33000 and $400000 \mathrm{~g} / \mathrm{mol}$. ALG extracted from different sources differ in $\mathrm{M}$ and $\mathrm{G}$ residues as well as the length of 


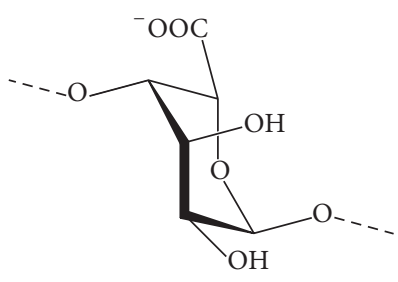

$1,4 \alpha$-L-Guluronic acid

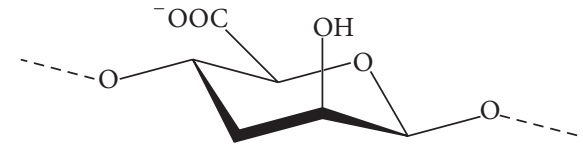

$1,4 \beta$-D-Mannuronic acid

(a)

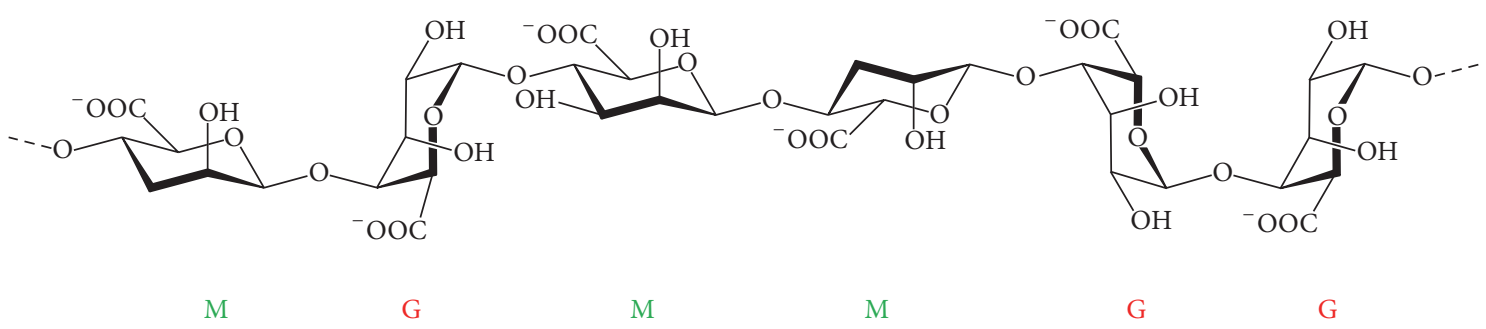

(b)

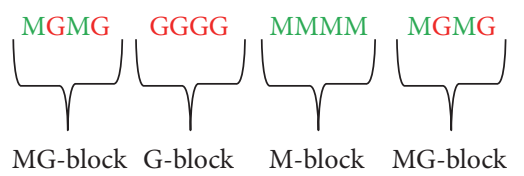

(c)

FigURE 1: The structure of ALG: monomers (a), chain conformation (b), and blocks distribution (c).

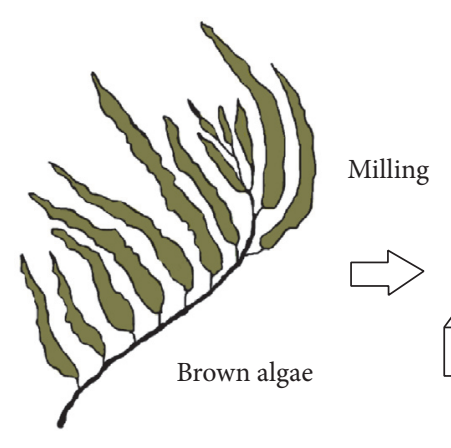

Mineral acid Sodium carbonate

Extraction
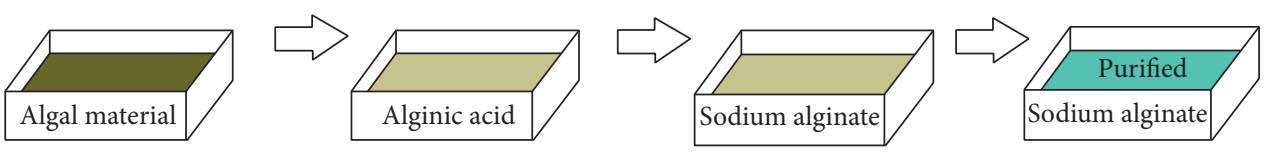

FIGURE 2: The procedure of sodium alginate extraction from brown algae [2].

each block. Generally, by raising the ALG G-block content or molecular weight, more stronger and brittle ALG gels may be achieved [67]. Alginic acid is insoluble in water and organic solvents, whereas ALG monovalent salts and ALG esters are water-soluble forming stable, viscous solutions [1-4]. The $1 \% w / v$ aqueous solution of sodium alginate has a dynamic viscosity $20-400 \mathrm{mPa} \cdot \mathrm{s}$ at $20^{\circ} \mathrm{C}$. ALG solubility is limited by the solvent $\mathrm{pH}$ (a decrease in $\mathrm{pH}$ below $\mathrm{pKa}$ 3.38-3.65 may lead to polymer precipitation), ionic strength, and the content of "gelling ions" [2, 68]. ALG with more heterogeneous structure (MG-blocks) are soluble at low $\mathrm{pH}$ compared to poly-M or poly-G ALG molecules, which precipitate under these conditions $[69,70]$. Apart from molecular weight, the ALG capability of creating viscous solutions may vary according to their concentration, solvent $\mathrm{pH}$ (a maximum $\mathrm{pH}$ is reached around 3.0-3.5), temperature, and the presence of divalent ions $[1-3,68]$.

ALG can be easily formed into diverse semisolid or solid structures under mild conditions because of their unique ability of sol/gel transition. Therefore, ALG are commonly used as viscosity increasing agents, thickeners, and suspension and emulsion stabilizers in food and pharmaceutical industry (Table 2).

ALG gelation can be induced in the presence of divalent ions, which cross-link the polymer chains through the "eggbox" model $[68,71,72]$ or by lowering the $\mathrm{pH}$ value below the $\mathrm{pKa}$ of ALG monomers using lactones like d-glucono- $\delta$ lactone $[2,4]$. It should be noted that calcium chloride, most frequently used source of $\mathrm{Ca}^{2+}$ ions, is responsible for rapid and uncontrollable ALG gelation. The gelation rate is a critical 
TABLE 1: Sodium alginate characteristic recommended by the European Pharmacopeia (Eur. Ph.) and United States Pharmacopeia (USP) $[5,6]$.

\begin{tabular}{|c|c|c|}
\hline Parameter & Eur. Ph. 8.0 & USP $32-N F 27$ \\
\hline Appearance of solid product & White or pale yellowish-brown powder & n.d. \\
\hline Content & n.d. & $90.8 \%-106.0 \%$ of dried basis \\
\hline Packaging and storage & n.d. & preserved in tight containers \\
\hline Solubility & Slowly soluble in water, practically insoluble in ethanol 96\% & n.d. \\
\hline Appearance of solution & $\begin{array}{l}\text { Not more opalescent than reference formazin suspension in water } \\
\text { and not more intensely coloured than intensity } 6 \text { of the range of } \\
\text { reference solutions of the most appropriate colour }\end{array}$ & n.d. \\
\hline Heavy metals & $\leq 20 \mathrm{ppm}$ & $\leq 0.004 \%$ \\
\hline Chlorides & $\leq 1.0 \%$ & n.d. \\
\hline Calcium & $\leq 1.5 \%$ & n.d. \\
\hline Arsenic & n.d. & $\leq 1.5 \mathrm{ppm}$ \\
\hline Loss on drying & $\leq 15.0 \%$ & $\leq 15.0 \%$ \\
\hline Total ash & n.d. & $18.0 \%-27.0 \%$ \\
\hline Sulfated ash & $30.0 \%-36.0 \%$ & n.d. \\
\hline Microbial limits & $\begin{array}{l}\text { TAMC: } \leq 1000 \mathrm{cfu} / \mathrm{g} \\
\text { TYMC: } \leq 100 \mathrm{cfu} / \mathrm{g}\end{array}$ & $\leq 200 \mathrm{cfu} / \mathrm{g}$ \\
\hline $\begin{array}{l}\text { Absence of specified } \\
\text { microorganisms }\end{array}$ & Salmonella sp., Escherichia coli & Salmonella sp., Escherichia coli \\
\hline
\end{tabular}

n.d.: not determined, TAMC: total aerobic microbial count, and TYMC: total yeast/moulds count.

TABLE 2: The use of alginic acid and its salts in food and pharmaceutical industry.

\begin{tabular}{|c|c|c|c|}
\hline Code & Ingredient & Application in food industry & Application in pharmaceutical industry \\
\hline E400 & Alginic acid [1] & Emulsifier, formulation aid, stabilizer, thickener & $\begin{array}{l}\text { Tablet binder and disintegrant, sustained release and } \\
\text { release-modifying agent, taste masking agent, thickener, } \\
\text { suspending and viscosity increasing agent, stabilizer }\end{array}$ \\
\hline E401 & $\begin{array}{l}\text { Sodium alginate } \\
{[4]}\end{array}$ & $\begin{array}{l}\text { Texturizer, stabilizer, thickener, formulation aid, } \\
\text { firming agent, flavour adjuvant, emulsifier, surface } \\
\text { active agent }\end{array}$ & $\begin{array}{l}\text { Suspending and viscosity increasing agent, tablet and } \\
\text { capsule disintegrant, tablet binder, stabilizer, sustained } \\
\text { release agent, diluent in capsule formulation, thickener }\end{array}$ \\
\hline E403 & $\begin{array}{l}\text { Ammonium } \\
\text { alginate [7] }\end{array}$ & Stabilizer, thickener, humectant & Color diluent, emulsifier, film former, humectant \\
\hline E404 & $\begin{array}{l}\text { Calcium alginate } \\
{[8]}\end{array}$ & Stabilizer, thickener & Tablet disintegrant \\
\hline E405 & $\begin{array}{l}\text { Propylene glycol } \\
\text { alginate } \\
\text { [9] }\end{array}$ & $\begin{array}{l}\text { Emulsifier, flavoring adjuvant, formulation aid, } \\
\text { stabilizer, surfactant, thickener }\end{array}$ & $\begin{array}{l}\text { Stabilizer, emulsifier, suspending and viscosity } \\
\text { increasing agent }\end{array}$ \\
\hline
\end{tabular}

parameter in controlling gelation process. Slow gelation provides creating uniform gel structures with mechanical integrity [67]. One approach to reducing the rate of gel forming process is to apply to phosphate buffers (e.g., sodium hexametaphosphate). In the reaction with ALG carboxylate groups, phosphate groups present in the buffer compete with calcium ions and as a result ALG gelation process is retarded [73]. Additionally, calcium sulfate and calcium carbonate with lower solubility also prolong the gel formation. The gelation rate is also dependent on temperature; at lower temperatures, the reactivity of $\mathrm{Ca}^{2+}$ is reduced [74]. Recently, a freeze-thaw technique has been examined as an advanced controlled method for ALG hydrogels formation [75]. Gelling properties are strongly associated with ALG structure and proportions of M-, G-, and MG-blocks [67, 71, 76]. In addition, ALG gels with an increased amount of repeating Gblock units are regarded as stiffer, brittle, and mechanically more stable [71, 72]. In contrast, ALG characterized by high proportion of M-blocks form gradually soft and more elastic gels. However, MG-blocks in ALG gel determine its shrinkage and higher flexibility [77]. Nevertheless, ALG with predominated M-block content, as a result of high water absorption, exchange ions more easily in comparison to ALG with higher amount of G-block residues [68, 71, 72, 78]. It should be noted that a number of studies revealed that ALG solution/gel transition occurred under physiological conditions, for example, in the presence of divalent ions and under acidic environment of body fluids [72]. For instance, nonwoven dressings of calcium alginate capable of exchange ions with the wound fluid have been commonly utilized 


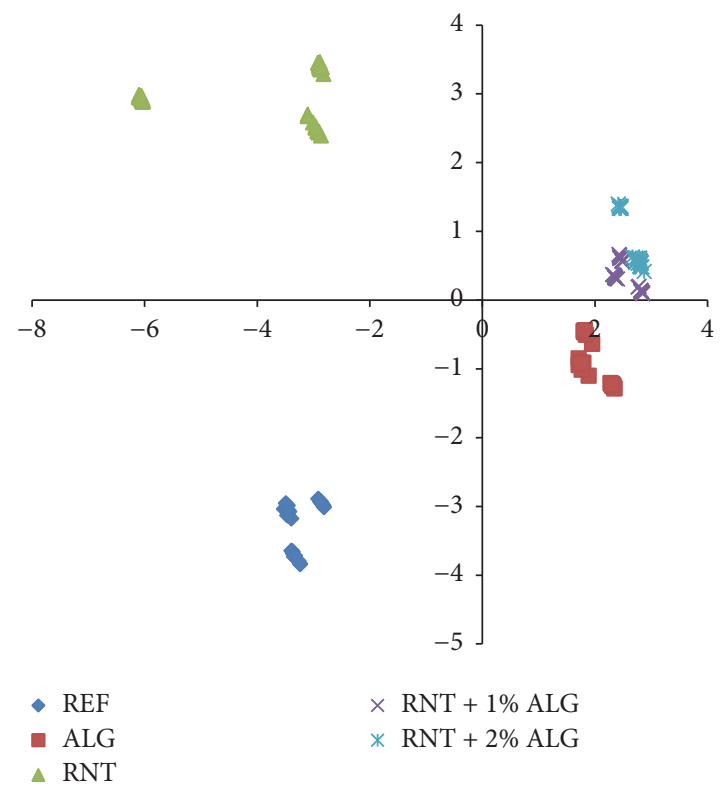

FIGURE 3: Potentiometric electronic tongue plot showing taste clusters of reference solution $\left(0.0001 \mathrm{M} \mathrm{Ca}\left(\mathrm{NO}_{3}\right)_{2}, 0.0001 \mathrm{M} \mathrm{NaCl}\right)(\mathrm{REF})$, pure ranitidine hydrochloride (RNT), microspheres placebo (ALG), and microspheres prepared with using $1 \%$ and $2 \%$ ALG solution (RNT + ALG $1 \%$ and RNT + ALG 2\%, resp.). Samples were placed in $100 \mathrm{~mL}$ of deionized water; measurement time was 7 min with signal acquisition every $5 \mathrm{~s}$. The data were processed using Principal Component Analysis (PCA) with autoscaling (author's original unpublished data).

for the treatment of exuding injuries or infected surgical wounds [79-81]. Formation of a highly absorbent soluble gel effectively maintains a physiologically moist environment and aids healing process through facilitating growth of fresh epidermis $[75,79]$. Due to mechanical stability and proper viscoelastic behavior, ALG are also applied as structural supporting biomaterials for tissue (teeth, bone, and cartilage) reconstruction [79].

The fact that ALG may undergo in situ gelation makes ALG materials promising tools for a wide range of applications, including injectable vehicles for tissue engineering or topical drug delivery systems [41, 79, 82]. Moreover, due to gelling properties, ALG have been investigated as taste masking agents $[83,84]$. Studies performed with using potentiometric electronic tongue [85] have proved that spraydried microspheres with sodium alginate hid the bitter taste of ranitidine hydrochloride through physical gel-barrier formation (Figure 3). Figure 3 presents final chemical image, which shows that for all samples distinctive clusters are easily observable. They are formed by chemical images of samples of various types, where ALG microspheres with ranitidine hydrochloride are easily discernable from pure drug, which indicates masking effect obtained with the use of sodium alginate.

Greatly porous three-dimensional ALG hydrogel structure displays favorable swelling properties arising from the presence of hydrophilic functional groups [86]. ALG ability of hydration and gel formation gives the opportunity to prolong release of the active substance at the administration site. Hence, these polymers have been extensively studied for prolonged or controlled release drug delivery systems $[87,88]$.
In addition, owing to the mild conditions during gel formation, ALG (especially calcium alginate) appear to be favorable tools for cell entrapment used in tissue engineering or regeneration [89-91]. ALG barrier protects immobilized material toward physical stress (maintaining its viability during long-term culture) and enables avoiding immunological reactions with the host. Currently, ALG microparticulate systems are also being developed for the treatment of a variety of diseases, including cancer, diabetes, or Parkinson's disease $[92,93]$.

ALG possess good mucoadhesive properties resulting from the presence of free carboxyl groups allowing the polymer to interact with mucin by hydrogen and electrostatic bonding. Environmental $\mathrm{pH}$ has a strong impact on ALG solubility and consequently on their mucoadhesive character as only ionized carboxyl groups are capable of interacting with mucosal tissue. In addition, soluble ALG facilitate solvent penetration through polymer matrix resulting in formation of more viscous and cohesive gel structure responsible for strengthening the mucoadhesive bonds. In contrary, too excessive hydration of ALG matrix in physiological fluids might weaken mucoadhesiveness as a result of attenuation of ALG functional groups available for interactions with mucosal tissue [94-96].

Owing to mucoadhesive properties, ALG are regarded as proper polymer excipients to prepare buccal [97-99], nasal $[100,101]$, ocular $[102,103]$, and gastrointestinal dosage forms [104-108]. Recently, several studies have shown favourable mucoadhesiveness of ALG-based applications in contact with vaginal mucosa tissue $[108,109]$. Furthermore, an increased drug residence time at the ocular mucosal surface and prolonged release of active agents from microparticulate 


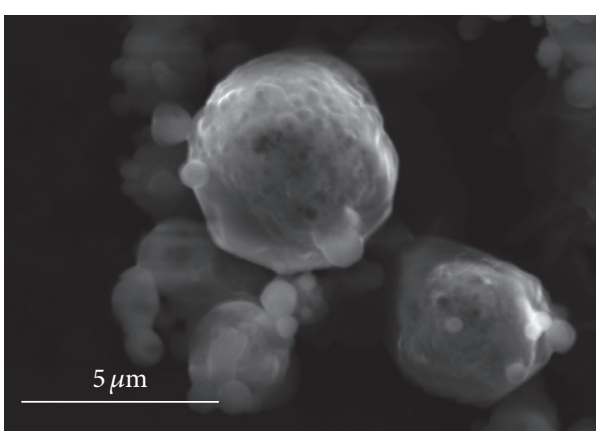

(a)

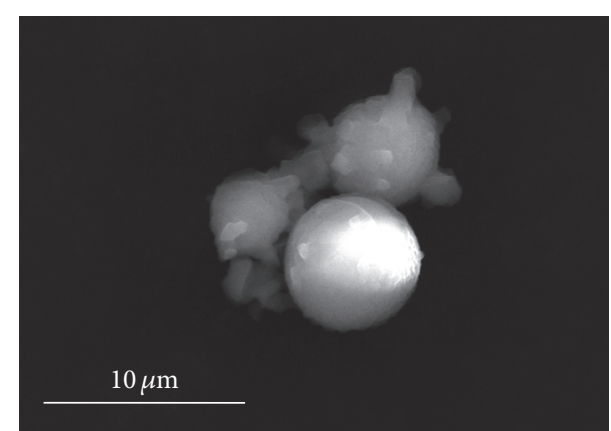

(b)

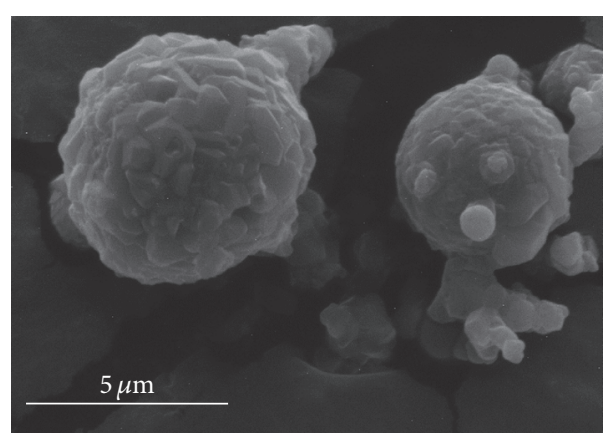

(c)

FIGURE 4: SEM images of alginate microspheres obtained by the spray drying method with metronidazole under magnification $\times 20000$ (a), ranitidine hydrochloride under magnification $\times 10000$ (b), and metformin hydrochloride under magnification $\times 20000$ (c) (author's unpublished images).

delivery systems with ALG were displayed [110]. Due to large surface area, which may favour an intimate contact between the polymer and mucin, multiunit dosage forms with sodium alginate are also explored as gastroretentive drug carriers (Figure 4), especially for substances, which are unstable or degraded in the alkaline $\mathrm{pH}[111,112]$.

ALG have been extensively evaluated as vaccine adjuvants or coadjuvants as these polymers were displayed to enhance bioavailability and immunogenicity of antigens after nasal and oral administration $[101,113,114]$.

\section{ALG Modification for Drug Delivery Systems and Biomedical Devices}

ALG can be easily modified through chemical or physical cross-linking in order to form ALG hydrogels and improve physicochemical properties and/or biological activity. Many methods have been described for ALG cross-linking, which includes ionic cross-linking, covalent cross-linking, cell cross-linking, phase transition (thermal gelation), "click" reaction, and free radical polymerization [89]. An alteration of the M- to G-block proportion or an enrichment of polymer backbone in M-, G-, or MG-blocks is being practiced by modification through enzymatic epimerisation catalysed by mannuronan C-5 epimerases. This enzyme, isolated from the soil bacterium Azotobacter vinelandii and expressed in Escherichia coli, converts mannuronic acid residues into guluronic acid residues in the polymer backbone without breaking of the glycosidic bond [87, 115, 116]. Additionally, from ALG backbone, oligosaccharides might be isolated, which are polymer fragments containing three to ten of simple monosaccharides. There are two methods, which might be used to prepare ALG oligosaccharides: enzymatic depolymerization and acid hydrolysis [56]. The common chemical modification of ALG hydroxyl groups includes oxidation, sulfation, graft copolymerization, acetylation, and phosphorylation process $[117,118]$. Modification of the carboxyl groups may be achieved by esterification and amidation $[89,117,118]$. A list of the commonly used chemical changes of ALG structure for biomedical and pharmaceutical application is presented in Table 3. ALG solubility might be changed by modification of hydroxyl groups (in positions $\mathrm{C} 2$ and $\mathrm{C} 3$ ) or the carboxyl groups (in C6 position) through covalent attachment of long alkyl chains or aromatic groups to the polymer backbone. Increasing ALG hydrophobicity provides decreasing polymer dissolution and erosion. Additionally, there are many studies, which include production of ALG derivatives by grafting with different substances such as polyacrylamide, methacrylate, galactose, lectin, sulfate, cysteine, cyclodextrins, propylene glycol, and dodecylamine [117-119].

\section{ALG Biological Activity and Application in Pharmaceutical Products}

ALG are regarded as biocompatible, nonimmunogenic, and nontoxic materials [2]. Although ALG gel is not degradable in mammalian digestive tract (alginase/lyase enzyme involved in depolymerization of ALG is present only in prokaryotic 
TABLE 3: Examples of chemically modified-alginate based drug delivery systems and biomedical devices.

\begin{tabular}{|c|c|c|c|c|c|}
\hline Type of modification & Material & Active substance & $\begin{array}{l}\text { Biomedical or } \\
\text { pharmaceutical application }\end{array}$ & Dosage form & Reference \\
\hline \multirow[t]{2}{*}{ Oxidation } & \multirow[t]{2}{*}{ Oxidized-NaALG } & $\begin{array}{l}\text { Limbal epithelial stem } \\
\text { cells }\end{array}$ & $\begin{array}{l}\text { Improvement of corneal } \\
\text { wound healing therapy }\end{array}$ & Hydrogel & Wright et al. [10] \\
\hline & & Flurbiprofen & Sustained oral delivery & Beads & Maiti et al. [11] \\
\hline $\begin{array}{l}\text { Reductive-amination } \\
\text { of oxidized alginate }\end{array}$ & $\begin{array}{l}\text { ALG-g-poly(ethylene } \\
\text { glycol) }\end{array}$ & $\begin{array}{l}\text { Human foreskin } \\
\text { fibroblasts }\end{array}$ & $\begin{array}{l}\text { Specific cell } \\
\text { microencapsulation }\end{array}$ & Microspheres & Mahou et al. [12] \\
\hline Sulfation & Sulfated ALG & - & $\begin{array}{l}\text { Reduction of secretion } \\
\text { inflammatory cytokines, } \\
\text { improvement of the } \\
\text { biocompatibility }\end{array}$ & Microspheres & Arlov et al. [13] \\
\hline \multirow[t]{3}{*}{ Phosphorylation } & Phosphorylated ALG & - & $\begin{array}{l}\text { Mineralization of } \\
\text { hydroxyapatite and } \\
\text { participation in the } \\
\text { chelation process for tissue } \\
\text { engineering }\end{array}$ & Gel & Coleman et al. [14] \\
\hline & $\begin{array}{l}\text { NaALG-co- } \\
\text { polyacrylamide }\end{array}$ & Famotidine & $\begin{array}{l}\text { Sustained release } \\
\text { gastroretentive carrier }\end{array}$ & Hydrogel & $\begin{array}{l}\text { Tripathi and } \\
\text { Mishra [15] }\end{array}$ \\
\hline & $\begin{array}{l}\text { Starch-g-poly(acrylic } \\
\text { acid)-NaALG }\end{array}$ & Diclofenac sodium & $\begin{array}{l}\mathrm{pH} \text {-sensitive matrices for } \\
\text { the oral drug delivery }\end{array}$ & Hydrogel beads & Chang [16] \\
\hline \multirow[t]{4}{*}{$\begin{array}{l}\text { Graft } \\
\text { copolymerization }\end{array}$} & $\begin{array}{l}\text { ALG-glycidyl } \\
\text { methacrylate }\end{array}$ & $\begin{array}{l}\text { Human endothelial } \\
\text { cell lines HUVEC and } \\
\text { L929 }\end{array}$ & $\begin{array}{l}\text { Thermal polymerizable } \\
\text { injectable hydrogel for } \\
\text { tissue engineering, } \\
\text { especially for myocardial } \\
\text { repair }\end{array}$ & Hydrogel & Wang et al. [17] \\
\hline & Galactosylated ALG & Hepatocytes & $\begin{array}{l}\text { Cell carrier with } \\
\text { mechanical stability and } \\
\text { selective permeability }\end{array}$ & Microcapsules & Tian et al. [18] \\
\hline & $\begin{array}{l}\alpha \text {-Cyclodextrin-ALG } \\
\text { conjugate }\end{array}$ & Sphingomonas cloacae & Immobilization of bacteria & Beads & Pluemsab et al. [19] \\
\hline & $\begin{array}{l}\beta \text {-Cyclodextrin-ALG } \\
\text { conjugate }\end{array}$ & Ondansetron & $\begin{array}{l}\text { Controlled drug delivery } \\
\text { systems }\end{array}$ & Gel & Izawa et al. [20] \\
\hline Esterification & Propylene glycol ALG & Lysozyme & $\begin{array}{l}\text { Protein encapsulation with } \\
\text { a sustained release }\end{array}$ & Microparticles & Hurteaux et al. [21] \\
\hline
\end{tabular}

and eukaryotic microorganisms) [120], it simply dissolves as a result of elution of cross-linking calcium ions. It should be noted that only small ALG molecules are excreted by renal clearance threshold. To enable complete elimination of ALG from the body, partial oxidation of polymer backbone is necessary [121]. ALG biocompatibility was confirmed in vivo after ocular [122], nasal [114], topical [123], local [124, 125], and oral administration [126]. Food and Drug Administration has recently affirmed several ALG salts (calcium, sodium, ammonium, and potassium) as well as propylene glycol ALG derivative as GRAS (generally regarded as safe) ingredients for oral administration [127]. Nevertheless, several data reported that chemical composition of ALG may affect polymers' immunogenicity. For instance, Otterlei et al. described that ALG with high M-block were much more potent in inducing cytokine production compared with ALG with high $\mathrm{G}$ constituents [128]. In addition, various impurities such as heavy metals, endotoxins, proteins, and polyphenol compounds present in ALG material could potentially exert immunogenic response $[129,130]$. Therefore, to assure high purity of ALG, proper decontamination methods should be applied concomitantly with extraction procedure [130].

ALG have been extensively studied for a wide range of applications. They include in situ gel formation, controlled release, targeted drug delivery, and medical purposes $[2,87$, 88]. List of the pharmaceutical products based on ALG is presented in Table 4.

ALG are known to act as a physical barrier in order to reduce reflux episodes $[131,132]$. A number of available ALGbased pharmaceutical products used for the symptomatic treatment of heartburn and oesophagitis exist [132]. As ALG formulations generally contain bicarbonate salt, it converted to carbon dioxide (entrapped within the gel matrix) enabling polymer to float on the surface of the gastric fluid. ALG-based products may retain in the stomach for several hours providing long-lasting relief [132-134]. Several studies revealed that sodium alginate is able to move to the oesophagus ahead of gastric contents and hence might be helpful in decreasing the number of acid esophageal episodes. Additionally, owing to mucoadhesive properties, ALG was demonstrated to protect 
TABLE 4: List of the pharmaceutical products based on ALG.

\begin{tabular}{|c|c|c|c|}
\hline Product & Main ingredients & Description & Indications \\
\hline & & \multirow{4}{*}{$\begin{array}{l}\text { Creates a mechanical barrier } \\
\text { between the stomach and the } \\
\text { esophagus which prevents the } \\
\text { reflux, recurrent symptoms of } \\
\text { respiratory, choking, dysphagia, } \\
\text { heartburn, belching, irritability; } \\
\text { accelerates gastric movement, } \\
\text { regenerates mucous membranes } \\
\text { of the esophagus and ensures its } \\
\text { protection }\end{array}$} & \multirow{3}{*}{$\begin{array}{l}\text { Children and infants from the first days of life } \\
\text { reflux treatment }\end{array}$} \\
\hline $\begin{array}{l}\text { Gastrotuss }^{\circledR} \\
\text { baby syrup } \\
{[22,23]}\end{array}$ & $\begin{array}{l}\text { Magnesium alginate, } \\
\text { simethicone, fructose, xanthan } \\
\text { gum, honey, D-panthenol, fluid } \\
\text { extracts of Althaea officinalis, } \\
\text { Papaver rhoeas, zinc oxide, } \\
\text { sodium bicarbonate, sodium } \\
\text { hydroxide }\end{array}$ & & \\
\hline $\begin{array}{l}\text { Algicid }^{\circledR} \text { sus- } \\
\text { pension/tablets } \\
{[24]}\end{array}$ & $\begin{array}{l}500 \mathrm{mg} \text { sodium alginate, } 100 \mathrm{mg} \\
\text { potassium bicarbonate per } \\
5 \mathrm{ml} / \text { per } 1 \text { tablet }\end{array}$ & & \\
\hline $\begin{array}{l}\text { Gaviscon } \\
\text { Double Action } \\
\text { Liquid }^{\circledR}[25]\end{array}$ & $\begin{array}{l}250 \mathrm{mg} \text { sodium alginate, } \\
106.5 \mathrm{mg} \text { sodium bicarbonate, } \\
\text { and } 162.5 \mathrm{mg} \text { calcium carbonate } \\
\text { per } 5 \mathrm{ml}\end{array}$ & & Adult reflux treatment \\
\hline $\begin{array}{l}\text { Gaviscon } \\
\text { Double Action } \\
\text { tablets }^{\circledR}[26]\end{array}$ & $\begin{array}{l}250 \mathrm{mg} \text { sodium alginate, } 106.5 \mathrm{mg} \\
\text { sodium bicarbonate, and } 187.5 \mathrm{mg} \\
\text { calcium carbonate per tablet }\end{array}$ & & \\
\hline
\end{tabular}

Dermal application

Hydrated alginates polymers in a polyethylene glycol (PEG) matrix Dissolution of dry scab and

Flaminal Forte ${ }^{\circledR}$ with a biologic enzyme system gel [27] based on glucose oxidase and lactoperoxidase stabilized by guaiacol

Purilon Gel ${ }^{\circledR}$ gel Carboxymethylcellulose, calcium [28] alginate Saf-Gel ${ }^{\circledR}$ gel [29] $\begin{aligned} & \text { Carbomer, propylene glycol } \\ & \text { sodium/calcium alginate }\end{aligned}$

Hyalogran ${ }^{\circledR} \quad$ Ester of hyaluronic acid (HA) dressing [30] and sodium alginate

SeaSorb ${ }^{\circledR}$ dressing [31]

Calcium alginate

Two-layer dressing built from hydrophilic polyurethane

Tromboguard $^{\circledR} \quad$ sponges and biologically active dressing [32] layer containing chitosan, sodium alginate, calcium alginate, and silver cations

Fibracol Plus ${ }^{\circledR} \quad 90 \%$ collagen and $10 \%$ calcium dressing [32] alginate

Algivon $^{\circledR}$ dressing [33]

Calcium alginate dressing impregnated with Manuka honey

Guardix-SG ${ }^{\circledR} \quad$ Sodium alginate, poloxamer, $[34,35]$ necrotic material, absorption of lysed material and bacteria by alginates in hydrated form

Provides moist environment at wound surface

Exudate absorbs and transforms to soft gel; removes necrotic tissue

Creates moist environment at wound surface, conversion soft fibres to wet gel

Strong haemostatic and antibacterial activity

Provides moist environment at wound surface, tissue granulation, epithelialisation, and healing

Binds of exudate, regeneration

Creates thermosensitive viscous gel in contact with body temperature and forms mechanical barrier separates injured tissues
Leg and diabetic ulcers, pressure sores, complex grazes, burns, oncology and wounds dermatosurgery

Dry and sloughy necrotic wounds, pressure and venous ulcers, second-degree burns, cuts, abrasions and skin tear, noninfected diabetic foot ulcers

Variety of exuding wounds including leg ulcers, pressure sores, ischemic and diabetic wounds, particularly those which are covered with slough and necrotic tissue or areas that are difficult to dress

Heavily exuding wounds including leg and pressure ulcers, diabetic ulcers and second-degree burns, cavity wounds

Control of bleeding traumatic and postoperative wounds

Exuding wounds including: full-thickness and partial-thickness wounds; pressure ulcers; venous ulcers; ulcers caused by mixed vascular etiologies; diabetic ulcers; second-degree burns

Sloughy, necrotic, and malodorous wounds

In spine and thyroid surgeries to reduction of the incidence postoperative adhesions 
TABLE 4: Continued.

\begin{tabular}{|c|c|c|c|}
\hline Product & Main ingredients & Description & Indications \\
\hline \multicolumn{4}{|c|}{ Rectal administration } \\
\hline $\begin{array}{l}\text { Natalsid }^{\circledR} \\
\text { suppositories } \\
{[36]}\end{array}$ & Sodium alginate & Anti-inflammatory local action & $\begin{array}{l}\text { Chronic haemorrhoids, proctosigmoiditis, and } \\
\text { chronic anal fissures after surgical interventions in } \\
\text { the area of the rectum }\end{array}$ \\
\hline \multicolumn{4}{|c|}{ Periodontal application } \\
\hline $\begin{array}{l}\text { Progenix putty } \\
\text { Progenix plus }{ }^{\circledR} \\
\text { injection [37] }\end{array}$ & $\begin{array}{l}\text { Demineralised bone matrix in } \\
\text { type- } 1 \text { bovine collagen and } \\
\text { sodium alginate }\end{array}$ & $\begin{array}{l}\text { Regeneration, complementation } \\
\text { of bone losses; periodontal } \\
\text { diseases }\end{array}$ & Bony voids or gaps of the skeletal system \\
\hline $\begin{array}{l}\text { Emdogain }{ }^{\circledR} \text { gel } \\
{[38-40]}\end{array}$ & $\begin{array}{l}\text { Enamel matrix derivative } \\
(\mathrm{EMD}), \text { propylene glycol alginate }\end{array}$ & $\begin{array}{l}\text { Regeneration, periodontal } \\
\text { diseases, paradontosis }\end{array}$ & $\begin{array}{l}\text { 1-, 2-, and 3-wall intrabony defects, class II } \\
\text { mandibular furcation defects with minimal } \\
\text { interproximal bone loss, recession defects }\end{array}$ \\
\hline \multicolumn{4}{|c|}{ Arthroscopic application } \\
\hline $\begin{array}{l}\text { ChondroArt } \\
3 \mathrm{D}^{\mathrm{TM}} \text { injection } \\
{[41]}\end{array}$ & $\begin{array}{l}\text { Autologous chondrocytes } \\
\text { situated on a hydrogel scaffold } \\
\text { built from connection of alginate } \\
\text { and agarose }\end{array}$ & $\begin{array}{l}\text { Increase production and growth } \\
\text { of cartilage }\end{array}$ & $\begin{array}{l}\text { Degenerative diseases of joints and backbones } \\
\text { (osteoarthrosis, osteochondrosis) }\end{array}$ \\
\hline
\end{tabular}

gastric mucosa from harmful activity of gastric fluid [131, 132, 134]. Antacid ALG products are generally regarded as safe and may be used in children and pregnant women [134].

ALG are also considered as promising candidates in obesity and type 2 diabetes treatment as they are able to attenuate the postprandial glycemic response by modulation of gastric emptying [135-138] or inhibition of glucose transporters and glucose intestinal absorption rate [137]. Additionally, there are studies which have also revealed that ALG mode of hypoglycemic action might be associated with the reduced activity of $\alpha$-amylase, intestinal enzyme responsible for hydrolyzing the bonds between glucose residues in carbohydrate polymers $[106,139]$.

Superior anti(hyper)lipidemic efficacy of ALG was also displayed. ALG were found to combine bile acids in the digestive tract and to reduce their intestinal reabsorption [140], which in consequence enhance their excretion [141143]. Furthermore, Houghton et al. suggested that ALG are capable of reducing pancreatic lipase activity by protonating active sites in enzyme's structure [144]. Calcium alginate was also reported to show hypocholesterolemic activity after oral administration as it was found to reduce plasma cholesterol level effectively in the rat model [140].

Numerous data have drawn attention to the use of ALG derivatives as antibacterial, antiviral, and antifungal agents $[145,146]$. Several mechanisms have been proposed to explain ALG antimicrobial activity. Negatively charged ALG were found to interact with the outer bacterial cellular surface, leading to its disruption and leakage of intracellular substances $[147,148]$. A decrease in membrane function by formation a viscous ALG layer around the cell preventing nutrient transport was also demonstrated [147]. In addition, antibacterial efficacy could be related to ALG chelation capacity responsible for modulating the production of toxins, microbial growth, and factors crucial for microorganisms stability. Bacteriostatic activity of ALG was proved against a wide variety of species, including Pseudomonas, Escherichia, Proteus, and Acinetobacter [42, 43]. Nonetheless, it ought to be point out that the antimicrobial activity of ALG differs substantially according to a number of factors, namely, molecular weight, M/G-block ratio, modification of their structure, environmental $\mathrm{pH}$, and the state of applied formulation [145].

Sulfated polysaccharides and alginic acid-containing fractions extracted from algae were found to exert antiviral efficacy against a number of viruses families, including Flaviviridae, Togaviridae, Rhabdoviridae, and Herpesviridae and might be helpful in treatment of virus infections [146, 149-151]. The mode of action may be related to the strong anionic charge of sulfated ALG capable of interacting with the positively charged host cell and, as a result, virus contact with the host cell is prevented and the viral material could not enter in the cells [61, 152-154]. In contrary, Meiyu et al. indicated that virus penetration was inhibited by physical barrier created by ALG around the cell [154]. Furthermore, studies performed by Son et al. revealed that ALG with high Mblock content possessed immunostimulating properties by activating macrophages responsible for excreting cytokines and cytotoxic factors [155].

Haemostatic efficacy of calcium alginate through platelets activation and thrombin generation was also displayed [156159] enabling polymer application in wound dressings [3033]. Furthermore, sulfated ALG derivative propylene glycol alginate sodium sulfate (PSS) is the first oral heparinoid approved by Chinese Food and Drug Administration and has been used as an anticoagulant drug for over 30 years [160].

Sodium alginate oligosaccharides have been reported to lower blood pressure [64]. The hypotensive mechanism appeared to be associated with calcium antagonist activity, especially toward voltage-operated calcium channels [65]. Sodium alginate oligosaccharides in dose $60 \mathrm{mg} /$ day were found to decrease blood pressure and to eliminate hypertension after 14 days of treatment, whereas Moriya et al. displayed polymers facility to prevent early-stage of kidney injury by decreasing the rate of glomerular filtration [66]. In addition, alginate potassium might be considered as promising agent for preventing cardiovascular complications associated with 
hypertension, including cardiac, renal hypertrophy in the risk of stroke occurrence [161].

Antioxidant and anti-inflammatory activity of alginate oligosaccharides was also observed. Alginate oligosaccharides were found to attenuate the production of nitric oxide, reactive oxygen species (ROS), prostaglandin E2, and cyclooxygenase COX-2 [57, 162-166]. Yamamoto et al. demonstrated that the mechanism underlying antioxidant effect of high mannuronic alginate was based on stimulating monocytes to secrete anti-inflammatory cytokines [164]. Additionally, because of chelating capacity, ALG are capable of binding toxins and heavy metals in the intestine, protecting cells from the carcinogenesis process $[57,60$, 163166]. Furthermore, Jeong et al. indicated that alginic acid exerted antianaphylactic activity relating to inhibition of histamine release from mast cells followed with downregulation of histidine decarboxylase and proinflammatory cytokines expression [167]. Moreover, studies performed by Uno et al. showed that alginic acid reduced IgE production in the serum of mice immunized with $\beta$ lactoglobulin [168]. Additionally, alginic acid at concentration of $0.01 \mu \mathrm{g} / \mathrm{ml}$ was found to reduce histamine release from rat peritoneal mast cells up to $60 \%[167]$.

\section{Future Perspectives}

5.1. ALG-Based Three-Dimensional (3D) Cell Culture Systems. 3D culture systems, macroporous structures prepared from using natural, synthetic polymers or their composites, with ability to reflect the native extracellular matrix and natural physiological conditions have been regarded as advanced technology for complex cellular physiology investigations, drug evaluation, and tissue engineering [169-171]. Among natural polymers, ALG, with regard to gel formation ability, mechanical strength, and interactions with cell via bioadhesive bonds, are considered to be promising material for cell and tissue culture and have been employed as 3D systems [89]. 3D material based on ionically gelled and dried ALG macroporous scaffolds creates favorable conditions for cellular attachment, proliferation, and differentiation. ALG scaffolds are able to turn into hydrogels upon rehydration following cell seeding. At present, two ALG-based 3D products for cell culture AlgiMatrix ${ }^{\circledR}$ (Thermo Fisher Scientific/Life Technologies, USA) and NovaMatrix ${ }^{\circledR}$ 3D (NovaMatrix, Norway) are commercially available in different formats of standard cell culture well plates $[172,173]$. AlgiMatrix is a lyophilized sponge prepared of pharmaceutical-grade ALG extracted from brown seaweed. After application of the cell suspension on the top surface of porous ALG-platform, the lyophilisate becomes hydrated and entraps cells inside its porous structure [174]. Unopened product is stable at room temperature up to 12 months. In contrary, NovaMatrix 3D comprises sterile ALG foam structure, a source of gel forming ions to initiate polymer gelation, and a vial of lyophilized ALG to be dissolved in a culture medium. Once the pores are filled with the ALG solution, in situ hydrogel is formed which enables fast and gentle cell immobilization under physiological conditions [170, 173].
5.2. Cell-Based Microparticles for Therapeutic Applications. Immobilization of living cells or cell inducing factors in ALG matrix is commonly used technique in tissue and cartilage engineering. Over the last ten years, an advanced research has been conducted on the development of cell transplantation therapy in long-term diabetes and neurodegenerative diseases treatment with using ALG-encapsulation technology Immupel $^{\mathrm{TM}}$ (LCT, Living Cell Technologies Limited, Australia). This selectively permeable system with ability to protect the encapsulated living cells from host immune system manages them to function and differentiate accurately [175177]. Currently, two ALG-based products, DIABECELL ${ }^{\circledR}$ and NTCELL ${ }^{\circledR}$, are in advanced stage of clinical investigations.

DIABECELL implant consists of microencapsulated neonatal porcine islets capable of secreting insulin. The single system is designed to be delivered into the patients abdomen during laparoscopy procedure. Each multilayer microcapsule comprises the inner core of ALG (M/G ratio 60:40) cross-linked with calcium chloride and coated with polyL-ornithine- (PLO-) polycationic polymer responsible for strengthening the capsule wall. To reduce the risk of immunogenicity arisen from the presence of PLO, the additional outer layer prepared of ALG is present [178, 179]. Recently additional modification of microcapsules shell by cross-linking the PLO surface with genipin has been employed in order to improve microcapsules biocompatibility. The clinical data displayed a statistically significant efficacy of DIABECELL in reduction of hypoglycemic episodes in patients with type 1 diabetes after transplantation [179]. Another example of porcine pancreatic islet cells encapsulation is monolayer cellular device (MCD) technology. A single capsule contains collagen matrix base and monolayer of porcine islet cells (monolayer allows for a faster kinetic diffusion relative to the cluster of islands) and then coated by gelled layer built of $3 \%(w / v)$ ALG. The capsules are formatted to a $1-32 \mathrm{~cm}$ sheet for subcutaneous implantation. The MCD was histologically examined after a resection. Surrounded tissues graft fibrosis or ALG degradation has not been observed. In comparison to nonencapsulated porcine islets, less level of lymphocytes and macrophages has been noted $[180,181]$.

NTCELL with choroid plexus cells encapsulated within Immupel platform has been displayed to regenerate damaged tissue and significantly restore function in humans with Parkinson's disease. Following implantation into an impaired site within the brain of model animals, NTCELL was found to promote the production of cerebrospinal fluid as well as nerve growth factors. In addition to Parkinson's disease, the product may have the potential to be utilized in a number of other neurodegenerative disorders, including Huntington's, Alzheimer's or motor neuronal diseases $[182,183]$.

5.3. Biological Activity of ALG Oligosaccharides. In recent years, ALG oligosaccharides, low molecular polymer fragments obtained by enzymatic depolymerization or acid hydrolysis at elevated temperatures, have received much attention because of their unique opportunity for combination treatment in which the polymer acts as the drug vehicle and concomitantly as an active part of the therapy [116]. 
TABLE 5: Examples of ALG oligosaccharides with biological activity and pharmaceutical application.

\begin{tabular}{|c|c|c|c|}
\hline Compound & Mechanism of action & $\begin{array}{l}\text { Biological activity and pharmaceutical } \\
\text { application }\end{array}$ & Reference \\
\hline $\begin{array}{l}\text { OligoG }^{\circledR} \\
\text { (ALG oligosaccharide) }\end{array}$ & $\begin{array}{l}\text { Regulation of mucus viscosity by } \\
\text { induction alterations in mucin surface } \\
\text { charge, formation porosity of the mucin } \\
\text { networks in cystic fibrosis sputum; } \\
\text { eradication bacterial and fungal lung } \\
\text { infections by modification of biofilm } \\
\text { structure together with growth } \\
\text { inhibition, improvement the efficiency of } \\
\text { conventional antibiotics against } \\
\text { multidrug resistant bacteria or fungi }\end{array}$ & $\begin{array}{l}\text { Cystic fibrosis, treatment of chronic } \\
\text { obstructive pulmonary disease (COPD), } \\
\text { improvement of antibacterial and } \\
\text { antifungal therapy, antifungal activity }\end{array}$ & $\begin{array}{l}\text { Khan et al. [42] } \\
\text { Pritchard et al. [43] } \\
\text { Powell et al. [44] }\end{array}$ \\
\hline $\begin{array}{l}\text { Heparinoid } 911 \text { (sulfated } \\
\text { high mannuronic and } \\
\text { guluronic } \\
\text { oligosaccharides) }\end{array}$ & $\begin{array}{l}\text { Interaction with glycoproteins present on } \\
\text { the cell surface, which leads to the } \\
\text { counteracting HIV-virus, prevention of } \\
\text { viral adsorption and inhibition of viral } \\
\text { reverse transcriptase; } \\
\text { inhibition of DNA polymerase of } \\
\text { hepatitis B virus }\end{array}$ & $\begin{array}{l}\text { HIV/AIDS, } \\
\text { hepatitis B virus }\end{array}$ & $\begin{array}{l}\text { Xin et al. [45] } \\
\text { Xin et al. [46] } \\
\text { Jiang et al. [47] } \\
\text { Wu et al. [48] }\end{array}$ \\
\hline $\begin{array}{l}\text { ALG oligosaccharides; } \\
\text { oligomannuronate } \\
\text { (HS971) }\end{array}$ & $\begin{array}{l}\text { Inhibition effect on neuroinflammation, } \\
\text { promotion effect on microglial } \\
\text { phagocytosis, protection neurons from } \\
\text { cell death by blocking oxidative stress, } \\
\text { inhibition of production of nitric oxide } \\
\text { and prostaglandin E2, expression of } \\
\text { inducible nitric oxide synthase and } \\
\text { cyclooxygenase 2, secretion of } \\
\text { proinflammatory cytokines, promotion of } \\
\text { the phagocytosis of amyloid } \beta \text { protein } \\
\text { through its interaction with toll-like } \\
\text { receptor } 4 \text { (TLR4) in microglia }\end{array}$ & $\begin{array}{l}\text { Alzheimer's disease and } \\
\text { neurodegenerative diseases }\end{array}$ & $\begin{array}{l}\text { Tusi et al. [49] } \\
\text { Zhou et al. [50] } \\
\text { Manigandan et al. [51] } \\
\text { Hu et al. [52] } \\
\text { Wang et al. [53] }\end{array}$ \\
\hline $\begin{array}{l}\text { Propylene glycol alginate } \\
\text { sodium sulfate } \\
\text { oligosaccharides (PSS) }\end{array}$ & $\begin{array}{l}\text { Inhibition of thrombin by interfering } \\
\text { with the coagulation cascade, } \\
\text { prolongation of the activated partial } \\
\text { thromboplastin time, clotting time and } \\
\text { reduction platelet aggregation }\end{array}$ & $\begin{array}{l}\text { Anticoagulant and antithrombotic } \\
\text { activity, blood viscosity reduction }\end{array}$ & $\begin{array}{l}\text { Ronghua et al. [54] } \\
\text { Xin et al. [55] }\end{array}$ \\
\hline $\begin{array}{l}\text { Guluronate } \\
\text { oligosaccharide }\end{array}$ & $\begin{array}{l}\text { Reduction of the production of nitric } \\
\text { oxide, prostaglandin E2, reactive oxygen } \\
\text { species, the expression of inducible nitric } \\
\text { oxide synthase and cyclooxygenase } 2 \text {, } \\
\text { secretion of proinflammatory cytokines } \\
\text { IL-1 and IL-6, reduction of the } \\
\text { inflammatory responses through } \\
\text { blocking the activation of nuclear factor } \\
\text { NF- } \kappa \text { B and mitogen-activated protein } \\
\text { kinases, inhibition lipid peroxidation }\end{array}$ & $\begin{array}{l}\text { Antioxidant and anti-inflammatory } \\
\text { activity, } \\
\text { protection cells from the carcinogenesis } \\
\text { process }\end{array}$ & $\begin{array}{l}\text { Falkeborg et al. [56] } \\
\text { Zhou et al [57] } \\
\text { An et al. [58] } \\
\text { Ji et al. [59] } \\
\text { Hu et al. [60] }\end{array}$ \\
\hline $\begin{array}{l}\text { Unsaturated guluronate } \\
\text { oligosaccharide }\end{array}$ & $\begin{array}{l}\text { Dose and time depend on induction of } \\
\text { production of nitric oxide, inducible } \\
\text { nitric oxide synthase, reactive oxygen } \\
\text { species and TNF- } \alpha \text {, induction of } \\
\text { macrophage to release nuclear factor } \\
\text { NF- } \kappa \text { B and mitogen-activated protein } \\
\text { kinase signaling pathways }\end{array}$ & Immunomodulatory activity & $\begin{array}{l}\mathrm{Xu} \text { et al. }[61] \\
\mathrm{Xu} \text { et al. }[62]\end{array}$ \\
\hline
\end{tabular}


TABLE 5: Continued.

\begin{tabular}{|c|c|c|c|}
\hline Compound & Mechanism of action & $\begin{array}{l}\text { Biological activity and pharmaceutical } \\
\text { application }\end{array}$ & Reference \\
\hline ALG oligosaccharides & Stimulation cecal and fecal microflora & Probiotic and prebiotic activity & Wang et al. [63] \\
\hline $\begin{array}{l}\text { Sodium alginate } \\
\text { oligosaccharides } \\
\text { (including unsaturated } \\
3 \alpha \text {-L-guluronate } \\
\text { and/or } \\
\beta \text {-D-mannuronate) }\end{array}$ & $\begin{array}{l}\text { Hypothesis mechanism involves blood } \\
\text { pressure reduction related to direct action } \\
\text { on vascular vessels, by effect on the } \\
\text { adrenergic nervous system or endothelial } \\
\text { cell function }\end{array}$ & Hypertension & $\begin{array}{l}\text { Terakado et al. [64] } \\
\text { Chaki et al. [65] } \\
\text { Moriya et al. [66] }\end{array}$ \\
\hline
\end{tabular}

Examples of ALG oligosaccharides with biological activity and pharmaceutical application were presented in Table 5.

OligoG ${ }^{\circledR}$, the highly purified oligomer with a high content of G-blocks and a relatively narrow molecular weight distribution, represents a novel therapeutic approach for treatment of microbial infections [184]. The unique mode of OligoG action is related to mucolytic activity and modification of biofilm formed by bacteria during colonization process. OligoG (at concentration of $10 \%$ ) is able to alter the biofilm surface charge and porosity, weakening its growth and as a result to damage pathogens cell membranes. OligoG was demonstrated to increase the efficiency of conventional antibiotics against several resistant pathogens, including Pseudomonas, Acinetobacter, and Burkholderia sp. [184, 185]. In addition, Tøndervik et al. indicated that OligoG improved antifungal activity of commonly used polyenes, azoles, and allylamines against Aspergillus and Candida strains [186]. OligoG is currently being tested as novel inhaled polymer therapy for the treatment of chronic respiratory disease. The advantage of OligoG is its suitability for pulmonary administration after simple dissolution in isotonic solvents followed with effective lung deposition and resistance to enzymatic degradation [43].

It should be noted that ALG oligosaccharides might be also considered as promising probiotic and prebiotic agents due to their beneficial effect on promoting the growth of Bifidobacterium sp. with simultaneous inhibition of Salmonella enteritidis colonization in the large intestine [187]. The influence on the balance of commensal bacteria could be attributed to immunostimulatory activity of oligosaccharides through ability to upregulate the production of antiinflammatory factors $[61,62]$.

Additionally, considerable research effort has been made to explore the usability of heparinoid ALG derivatives to support HIV treatment. At present, drug 911, sulfated high mannuronic and guluronic heterogeneous fragments of ALG, belonging to a group of heparinoid polysaccharides, is in advanced phase of clinical investigations in China as antiAIDS drug [45-48]. Heparinoid 911 possesses an average molecular weight of $10 \mathrm{kDa}$ and 1.5 sulfates and 1.0 carboxyl groups per sugar residue [48]. Heparinoid 911 was demonstrated to interact with the positively charged regions of glycoproteins present on the cell surface, leading to the shielding effect on these regions, thus counteracting HIVvirus binding to the cell surface $[45,46]$. The unique mode of 911 action was found to be related to the inhibition of viral reverse transcriptase and prevention of viral adsorption. Furthermore, a significant inhibitory effect on DNA polymerase of hepatitis $B$ virus was also reported which gives the opportunity to apply 911 in hepatitis B treatment [47].

\section{Conclusions}

Owing to unique properties, swelling capacity, mucoadhesiveness, and ability of sol/gel transition ALG have gained a preferential place in the development of advanced drug delivery systems. These natural, multifunctional polymers are widely studied in the design of microparticulate systems for controlled release, targeted drug delivery, and biomedical application (as matrix for three-dimensional tissue cultures, adjuvants of antibiotics, and antiviral agents or in cell transplantation in diabetes and neurodegenerative diseases treatment). Additionally, highly absorbent ALG-based hydrogels with mechanical stability and viscoelastic properties are applied as wound dressing. This paper also describes ALG chemical modifications, ALG biological activity, and application in pharmaceutical products.

\section{Competing Interests}

The authors declare no conflict of interests.

\section{Acknowledgments}

This study was supported by Medical University of Białystok Grant (no. N/ST/MN/16/001/2215).

\section{References}

[1] M. A. Repka and A. Singh, "Alginic acid," in Handbook of Pharmaceutical Excipients, pp. 20-22, Pharmaceutical Press, London, UK, 6th edition, 2009.

[2] K. N. Sachan, S. Pushkar, A. Jha, and A. Bhattcharya, "Sodium alginate: the wonder polymer for controlled drug delivery," Journal of Pharmacy Research, vol. 2, no. 8, pp. 1191-1199, 2009.

[3] U. Remminghorst and B. H. A. Rehm, "Bacterial alginates: from biosynthesis to applications," Biotechnology Letters, vol. 28, no. 21, pp. 1701-1712, 2006.

[4] C. G. Cable, "Sodium alginate," in Handbook of Pharmaceutical Excipients, pp. 622-624, Pharmaceutical Press, London, UK, 6th edition, 2009. 
[5] The United States Pharmacopeia, "The United States pharmacopeial convention," USP 34-NF 29, The United States Pharmacopeial Convention, Rockville, Md, USA, 2011.

[6] Council of Europe, The European Pharmacopoeia 7.0, Council of Europe, Strasbourg, France, 2011.

[7] S. A. Shah and D. Thassu, "Ammonium alginate," in Handbook of Pharmaceutical Excipients, p. 41, Pharmaceutical Press, London, UK, 6th edition, 2009.

[8] C. G. Gable, "Calcium alginate," in Handbook of Pharmaceutical Excipients, pp. 83-85, Pharmaceutical Press, London, UK, 6th edition, 2009.

[9] R. G. Nause, R. D. Reddy, and J. L. P. Soh, "Propylene glycol alginate," in Handbook of Pharmaceutical Excipients, pp. 594595, Pharmaceutical Press, London, UK, 6th edition, 2009.

[10] B. Wright, P. A. De Bank, K. A. Luetchford, F. R. Acosta, and C. J. Connon, "Oxidized alginate hydrogels as niche environments for corneal epithelial cells," Journal of Biomedical Materials Research-Part A, vol. 102, no. 10, pp. 3393-3400, 2014.

[11] S. Maiti, K. Singha, S. Ray, P. Dey, and B. Sa, "Adipic acid dihydrazide treated partially oxidized alginate beads for sustained oral delivery of flurbiprofen," Pharmaceutical Development and Technology, vol. 14, no. 5, pp. 461-470, 2009.

[12] R. Mahou, R. R. H. Meier, L. H. Bühler, and C. Wandrey, "Alginate-poly(ethylene glycol) hybrid microspheres for primary cell microencapsulation," Materials, vol. 7, no. 1, pp. 275286, 2014.

[13] Ø. Arlov, G. Skjåk-Bræk, and A. M. Rokstad, "Sulfated alginate microspheres associate with factor $\mathrm{H}$ and dampen the inflammatory cytokine response," Acta Biomaterialia, vol. 42, pp. 180188, 2016.

[14] R. J. Coleman, G. Lawrie, L. K. Lambert, M. Whittaker, K. S. Jack, and L. Grndahl, "Phosphorylation of alginate: synthesis, characterization, and evaluation of in vitro mineralization capacity," Biomacromolecules, vol. 12, no. 4, pp. 889-897, 2011.

[15] R. Tripathi and B. Mishra, "Development and evaluation of sodium alginate-polyacrylamide graft-co-polymer-based stomach targeted hydrogels of famotidine," AAPS PharmSciTech, vol. 13, no. 4, pp. 1091-1102, 2012.

[16] A. Chang, "pH-sensitive starch-g-poly(acrylic acid)/sodium alginate hydrogels for controlled release of diclofenac sodium," Iranian Polymer Journal, vol. 24, no. 2, pp. 161-169, 2015.

[17] X. Wang, T. Hao, J. Qu, C. Wang, and H. Chen, "Synthesis of thermal polymerizable alginate-GMA hydrogel for cell encapsulation," Journal of Nanomaterials, vol. 2015, Article ID 970619, 8 pages, 2015.

[18] M. Tian, B. Han, H. Tan, and C. You, "Preparation and characterization of galactosylated alginate-chitosan oligomer microcapsule for hepatocytes microencapsulation," Carbohydrate Polymers, vol. 112, pp. 502-511, 2014.

[19] W. Pluemsab, Y. Fukazawa, T. Furuike, Y. Nodasaka, and N. Sakairi, "Cyclodextrin-linked alginate beads as supporting materials for Sphingomonas cloacae, a nonylphenol degrading bacteria," Bioresource Technology, vol. 98, no. 11, pp. 2076-2081, 2007.

[20] H. Izawa, K. Kawakami, M. Sumita, Y. Tateyama, J. P. Hill, and K. Ariga, " $\beta$-Cyclodextrin-crosslinked alginate gel for patient-controlled drug delivery systems: regulation of hostguest interactions with mechanical stimuli," Journal of Materials Chemistry B, vol. 1, no. 16, pp. 2155-2161, 2013.

[21] R. Hurteaux, F. Edwards-Lévy, D. Laurent-Maquin, and M.-C. Lévy, "Coating alginate microspheres with a serum albuminalginate membrane: application to the encapsulation of a peptide," European Journal of Pharmaceutical Sciences, vol. 24, no. 2-3, pp. 187-197, 2005.

[22] Clinical Trials (Internet), U.S. National Institutes of Health, https://clinicaltrials.gov/ct2/show/NCT01858584?term=magnesium+alginate\&rank $=1$.

[23] D. Ummarino, E. Miele, M. Martinelli et al., "Effect of magnesium alginate plus simethicone on gastroesophageal reflux in infants," Journal of Pediatric Gastroenterology and Nutrition, vol. 60, no. 2, pp. 230-235, 2015.

[24] Md. Jakaria, R. Zaman, M. Parvez et al., "Comparative study among the different formulation of antacid tablets by using acid-base neutralization reaction," Global Journal of Pharmacology, vol. 9, no. 3, pp. 278-281, 2015.

[25] A. De Ruigh, S. Roman, J. Chen, J. E. Pandolfino, and P. J. Kahrilas, "Gaviscon Double Action Liquid (antacid \& alginate) is more effective than antacid in controlling post-prandial oesophageal acid exposure in GERD patients: a double-blind crossover study," Alimentary Pharmacology and Therapeutics, vol. 40, no. 5, pp. 531-537, 2014.

[26] E. Thomas, A. Wade, G. Crawford, B. Jenner, N. Levinson, and J. Wilkinson, "Randomised clinical trial: relief of upper gastrointestinal symptoms by an acid pocket-targeting alginateantacid (Gaviscon Double Action) - a double-blind, placebocontrolled, pilot study in gastro-oesophageal reflux disease," Alimentary Pharmacology and Therapeutics, vol. 39, no. 6, pp. 595-602, 2014.

[27] Z. M. Rashaan, P. Krijnen, M. E. van den Akker- van Marle et al., "Clinical effectiveness, quality of life and cost-effectiveness of Flaminal ${ }^{\circledR}$ versus Flamazine ${ }^{\circledR}$ in the treatment of partial thickness burns: study protocol for a randomized controlled trial," Trials, vol. 17, article122, 9 pages, 2016.

[28] E. Caló and V. V. Khutoryanskiy, "Biomedical applications of hydrogels: a review of patents and commercial products," European Polymer Journal, vol. 65, pp. 252-267, 2015.

[29] C. Sussman and B. Bates-Jensen, "Management of the wound environment with dressings and topical agents," in Wound Care a Collaborative Practice Manual for Health Professionals, p. 254, Lippincott Williams \& Wilkins, 3rd edition, 2007.

[30] S. Carella, M. Maruccia, P. Fino, and M. G. Onesti, "An atypical case of Henoch-Shönlein purpura in a young patient: treatment of the skin lesions with hyaluronic acid-based dressings," In Vivo, vol. 27, no. 1, pp. 147-151, 2013.

[31] E. Ausili, V. Paolucci, S. Triarico et al., "Treatment of pressure sores in spina bifida patients with calcium alginate and foam dressings," European Review for Medical and Pharmacological Sciences, vol. 17, no. 12, pp. 1642-1647, 2013.

[32] S. Bale, N. Baker, H. Crook, A. Rayman, G. Rayman, and K. G. Harding, "Exploring the use of an alginate dressing for diabetic foot ulcers," Journal of Wound Care, vol. 10, no. 3, pp. 81-84, 2001.

[33] M. Porter and J. Kelly, "Pressure ulcer treatment in a patient with spina bifida," Nursing Standard, vol. 28, no. 35, pp. 60-69, 2014.

[34] E. J. Sohn, H. B. Ahn, M. S. Roh, W. Y. Ryu, and Y. H. Kwon, "Efficacy of temperature-sensitive guardix-sg for adhesiolysis in experimentally induced eyelid adhesion in rabbits," Ophthalmic Plastic and Reconstructive Surgery, vol. 29, no. 6, pp. 458-463, 2013.

[35] S. O. Park, J. Han, K. W. Minn, and U. S. Jin, "Prevention of capsular contracture with Guardix-SG ${ }^{\circledR}$ after silicone implant insertion," Aesthetic Plastic Surgery, vol. 37, no. 3, pp. 543-548, 2013. 
[36] L. Abramowitz, G. H. Weyandt, B. Havlickova et al., "The diagnosis and management of haemorrhoidal disease from a global perspective," Alimentary Pharmacology and Therapeutics, vol. 31, supplement 1, pp. 1-58, 2010.

[37] E. Gruskin, B. A. Doll, F. W. Futrell, J. P. Schmitz, and J. O. Hollinger, "Demineralized bone matrix in bone repair: history and use," Advanced Drug Delivery Reviews, vol. 64, no. 12, pp. 1063-1077, 2012.

[38] E. Al Machot, T. Hoffmann, K. Lorenz, I. Khalili, and B. Noack, "Clinical outcomes after treatment of periodontal intrabony defects with nanocrystalline hydroxyapatite (Ostim) or enamel matrix derivatives (Emdogain): a randomized controlled clinical trial," BioMed Research International, vol. 2014, Article ID 786353, 9 pages, 2014.

[39] X. Z. Yan, F. Rathe, C. Gilissen et al., "The effect of enamel matrix derivative (Emdogain ${ }^{\circledR}$ ) on gene expression profiles of human primary alveolar bone cells," Journal of Tissue Engineering and Regenerative Medicine, vol. 8, no. 6, pp. 463-472, 2014.

[40] A. Sculean, T. M. Auschill, N. Donos, M. Brecx, and N. B. Arweiler, "Effect of an enamel matrix protein derivative (Emdogain) on ex vivo dental plaque vitality," Journal of Clinical Periodontology, vol. 28, no. 11, pp. 1074-1078, 2001.

[41] A. Barzegari and A. A. Saei, "An update to space biomedical research: tissue engineering in microgravity bioreactors," BioImpacts, vol. 2, no. 1, pp. 23-32, 2012.

[42] S. Khan, A. Tøndervik, H. Sletta et al., "Overcoming drug resistance with alginate oligosaccharides able to potentiate the action of selected antibiotics," Antimicrobial Agents and Chemotherapy, vol. 56, no. 10, pp. 5134-5141, 2012.

[43] M. F. Pritchard, L. C. Powell, G. E. Menzies et al., "A new class of safe oligosaccharide polymer therapy to modify the mucus barrier of chronic respiratory disease," Molecular Pharmaceutics, vol. 13, no. 3, pp. 863-872, 2016.

[44] L. C. Powell, M. F. Pritchard, C. Emanuel et al., "A nanoscale characterization of the interaction of a novel alginate oligomer with the cell surface and motility of Pseudomonas aeruginosa," American Journal of Respiratory Cell and Molecular Biology, vol. 50, no. 3, pp. 483-492, 2014.

[45] X. L. Xin, M. Y. Geng, H. S. Guan, and Z. L. Li, "Study on the mechanism of inhibitory action of 911 on replication of HIV-1 in vitro," Chinese Journal of Marine Drugs, vol. 19, no. 4, pp. 15-18, 2000.

[46] X. L. Xin, H. Ding, M. Y. Geng, P. F. Liang, Y. X. Li, and H. S. Guan, "Studies of the anti-AIDS effects of marine polysaccharide drug 911 and its related mechanisms of action," Chinese Journal of Marine Drugs, vol. 19, no. 6, pp. 4-8, 2000.

[47] B. F. Jiang, X. F. Xu, L. Li, and W. Yuan, “Study on '911' anti-HBV effect in HepG2.2.15 cells culture," Modern Preventive Medicine, no. 30, pp. 517-518, 2003.

[48] Y.-L. Wu, J. Ai, J.-M. Zhao et al., "Sulfated polymannuroguluronate inhibits Tat-induced SLK cell adhesion via a novel binding site, a KKR spatial triad," Acta Pharmacologica Sinica, vol. 32, no. 5, pp. 647-654, 2011.

[49] S. K. Tusi, L. Khalaj, G. Ashabi, M. Kiaei, and F. Khodagholi, "Alginate oligosaccharide protects against endoplasmic reticulum- and mitochondrial-mediated apoptotic cell death and oxidative stress," Biomaterials, vol. 32, no. 23, pp. 54385458, 2011.

[50] R. Zhou, X.-Y. Shi, D.-C. Bi, W.-S. Fang, G.-B. Wei, and X. Xu, "Alginate-derived oligosaccharide inhibits neuroinflammation and promotes microglial phagocytosis of $\beta$-amyloid," Marine Drugs, vol. 13, no. 9, pp. 5828-5846, 2015.
[51] V. Manigandan, R. Karthik, and R. Saravanan, "Marine carbohydrate based therapeutics for Alzheimer disease-mini review," Journal of Neurology and Neuroscience, In press.

[52] J. Hu, M. Geng, J. Li et al., "Acidic oligosaccharide sugar chain, a marine-derived acidic oligosaccharide, inhibits the cytotoxicity and aggregation of amyloid beta protein," Journal of Pharmacological Sciences, vol. 95, no. 2, pp. 248-255, 2004.

[53] S. Wang, J. Li, W. Xia, and M. Geng, "A marine-derived acidic oligosaccharide sugar chain specifically inhibits neuronal cell injury mediated by $\beta$-amyloid-induced astrocyte activation in vitro," Neurological Research, vol. 29, no. 1, pp. 96-102, 2007.

[54] H. Ronghua, D. Yumin, and Y. Jianhong, "Preparation and in vitro anticoagulant activities of alginate sulfate and its quaterized derivatives," Carbohydrate Polymers, vol. 52, no. 1, pp. 19-24, 2003.

[55] M. Xin, L. Ren, Y. Sun et al., "Anticoagulant and antithrombotic activities of low-molecular-weight propylene glycol alginate sodium sulfate (PSS)," European Journal of Medicinal Chemistry, vol. 114, pp. 33-40, 2016.

[56] M. Falkeborg, L.-Z. Cheong, C. Gianfico et al., "Alginate oligosaccharides: enzymatic preparation and antioxidant property evaluation," Food Chemistry, vol. 164, pp. 185-194, 2014.

[57] R. Zhou, X. Shi, Y. Gao, N. Cai, Z. Jiang, and X. Xu, "Antiinflammatory activity of guluronate oligosaccharides obtained by oxidative degradation from alginate in lipopolysaccharideactivated murine macrophage RAW 264.7 cells," Journal of Agricultural and Food Chemistry, vol. 63, no. 1, pp. 160-168, 2015.

[58] Q.-D. An, G.-L. Zhang, H.-T. Wu et al., "Alginate-deriving oligosaccharide production by alginase from newly isolated Flavobacterium sp. LXA and its potential application in protection against pathogens," Journal of Applied Microbiology, vol. 106, no. 1, pp. 161-170, 2009.

[59] J. Ji, L. Wang, H. Wu, and H. Luan, "Bio-function summary of marine oligosaccharides," International Journal of Biology, vol. 3, no. 1, pp. 74-86, 2011.

[60] X. Hu, X. Jiang, H. Hwang, S. Liu, and H. Guan, "Antitumour activities of alginate-derived oligosaccharides and their sulphated substitution derivatives," European Journal of Phycology, vol. 39, no. 1, pp. 67-71, 2004.

[61] X. Xu, X. Wu, Q. Wang et al., "Immunomodulatory effects of alginate oligosaccharides on murine macrophage RAW264.7 cells and their structure-activity relationships," Journal of Agricultural and Food Chemistry, vol. 62, no. 14, pp. 3168-3176, 2014.

[62] X. Xu, D. Bi, X. Wu et al., "Unsaturated guluronate oligosaccharide enhances the antibacterial activities of macrophages," FASEB Journal, vol. 28, no. 6, pp. 2645-2654, 2014.

[63] Y. Wang, F. Han, B. Hu, J. Li, and W. Yu, "In vivo prebiotic properties of alginate oligosaccharides prepared through enzymatic hydrolysis of alginate," Nutrition Research, vol. 26, no. 11, pp. 597-603, 2006.

[64] S. Terakado, M. Ueno, Y. Tamura et al., "Sodium alginate oligosaccharides attenuate hypertension and associated kidney damage in Dahl salt-sensitive rats fed a high-salt diet," Clinical and Experimental Hypertension, vol. 34, no. 2, pp. 99-106, 2012.

[65] T. Chaki, N. Kajimoto, H. Ogawa, T. Baba, and N. Hiura, "Metabolism and calcium antagonism of sodium alginate oligosaccharides," Bioscience, Biotechnology and Biochemistry, vol. 71, no. 8, pp. 1819-1825, 2007.

[66] C. Moriya, Y. Shida, Y. Yamane et al., "Subcutaneous administration of sodium alginate oligosaccharides prevents saltinduced hypertension in dahl salt-sensitive rats," Clinical and Experimental Hypertension, vol. 35, no. 8, pp. 607-613, 2013. 
[67] C. K. Kuo and P. X. Ma, "Ionically crosslinked alginate hydrogels as scaffolds for tissue engineering: part 1 . Structure, gelation rate and mechanical properties," Biomaterials, vol. 22, no. 6, pp. 511$521,2001$.

[68] K. I. Draget, G. Skjåk Bræk, and O. Smidsrød, "Alginic acid gels: the effect of alginate chemical composition and molecular weight," Carbohydrate Polymers, vol. 25, no. 1, pp. 31-38, 1994.

[69] D. Brault, A. Heyraud, V. Lognone, and M. Roussel, "Methods for obtaining oligomannuronates and guluronates, products obtained and use thereof," Patent WO03099870, 2003.

[70] T. Shimokawa, S. Yoshida, T. Takeuchi, K. Murata, T. Ishii, and I. Kusakabe, "Preparation of two series of oligo-guluronic acids from sodium alginate by acid hydrolysis and enzymatic degradation," Bioscience, Biotechnology and Biochemistry, vol. 60, no. 9, pp. 1532-1534, 1996.

[71] K. I. Draget, M. K. Simensen, E. Onsøyen, and O. Smidsrød, "Gel strength of Ca-limited alginate gels made in situ," Hydrobiologia, vol. 260-261, no. 1, pp. 563-565, 1993.

[72] S. Fu, A. Thacker, D. M. Sperger et al., "Relevance of rheological properties of sodium alginate in solution to calcium alginate gel properties," AAPS PharmSciTech, vol. 12, no. 2, pp. 453-460, 2011.

[73] B. B. Crow and K. D. Nelson, "Release of bovine serum albumin from a hydrogel-cored biodegradable polymer fiber," Biopolymers, vol. 81, no. 6, pp. 419-427, 2006.

[74] A. D. Augst, H. J. Kong, and D. J. Mooney, "Alginate hydrogels as biomaterials," Macromolecular Bioscience, vol. 6, no. 8, pp. 623633, 2006.

[75] Y. Zhao, W. Shen, Z. Chen, and T. Wu, "Freeze-thaw induced gelation of alginates," Carbohydrate Polymers, vol. 148, pp. 45$51,2016$.

[76] W. R. Gombotz and S. F. Wee, "Protein release from alginate matrices," Advanced Drug Delivery Reviews, vol. 31, no. 3, pp. 267-285, 1998.

[77] T. E. Jørgensen, M. Sletmoen, K. I. Draget, and B. T. Stokke, "Influence of oligoguluronates on alginate gelation, kinetics, and polymer organization," Biomacromolecules, vol. 8, no. 8, pp. 2388-2397, 2007.

[78] B. Niekraszewicz and A. Niekraszewicz, "The structure of alginate, chitin and chitosan fibres," in Handbook of Textile Fibre Structure, pp. 266-304, Woodhead Publishing Limited, Cambridge, UK, 2009.

[79] E. A. Wahl, F. A. Fierro, T. R. Peavy et al., "In vitro evaluation of scaffolds for the delivery of mesenchymal stem cells to wounds," BioMed Research International, vol. 2015, Article ID 108571, 14 pages, 2015.

[80] J. W. Doyle, T. P. Roth, R. M. Smith, Y.-Q. Li, and R. M. Dunn, "Effect of calcium alginate on cellular wound healing processes modeled in vitro," Journal of Biomedical Materials Research, vol. 32, no. 4, pp. 561-568, 1996.

[81] S. Thomas, "Alginate dressings in surgery and wound management-Part 1," Journal of Wound Care, vol. 9, no. 2, pp. 56-60, 2000.

[82] H. Almeida, M. H. Amaral, P. Lobão, and J. M. S. Lobo, "In situ gelling systems: a strategy to improve the bioavailability of ophthalmic pharmaceutical formulations," Drug Discovery Today, vol. 19, no. 4, pp. 400-412, 2014.

[83] A. Michael Rajesh, S. A. Bhatt, H. Brahmbhatt, P. S. Anand, and K. M. Popat, "Taste masking of ciprofloxacin by ion-exchange resin and sustain release at gastric-intestinal through interpenetrating polymer network," Asian Journal of Pharmaceutical Sciences, vol. 10, no. 4, pp. 331-340, 2014.
[84] M. Jelvehgari, L. Barghi, and F. Barghi, "Preparation of chlorpheniramine maleate-loaded alginate/chitosan particulate systems by the ionic gelation method for taste masking," Jundishapur Journal of Natural Pharmaceutical Products, vol. 9, no. 1, pp. 39-48, 2014.

[85] P. Ciosek, M. Wesoły, M. Zabadaj et al., "Towards flowthrough/flow injection electronic tongue for the analysis of pharmaceuticals," Sensors and Actuators, B: Chemical, vol. 207, pp. 1087-1094, 2015.

[86] K. Y. Lee and D. J. Mooney, "Alginate: properties and biomedical applications," Progress in Polymer Science, vol. 37, no. 1, pp. 106126, 2012.

[87] H. H. Tønnesen and J. Karlsen, "Alginate in drug delivery systems," Drug Development and Industrial Pharmacy, vol. 28, no. 6, pp. 621-630, 2002.

[88] A. L. Ching, C. V. Liew, L. W. Chan, and P. W. S. Heng, "Modifying matrix micro-environmental $\mathrm{pH}$ to achieve sustained drug release from highly laminating alginate matrices," European Journal of Pharmaceutical Sciences, vol. 33, no. 4-5, pp. 361-370, 2008.

[89] J. Sun and H. Tan, "Alginate-based biomaterials for regenerative medicine applications," Materials, vol. 6, no. 4, pp. 1285-1309, 2013.

[90] E. García-Gareta, N. Ravindran, V. Sharma, S. Samizadeh, and J. F. Dye, "A novel multiparameter in vitro model of threedimensional cell ingress into scaffolds for dermal reconstruction to predict in vivo outcome," BioResearch Open Access, vol. 2, no. 6, pp. 412-420, 2013.

[91] W. Zhang and X. He, "Microencapsulating and banking living cells for cell-based medicine," Journal of Healthcare Engineering, vol. 2, no. 4, pp. 427-446, 2011.

[92] R. Calafiore and G. Basta, "Clinical application of microencapsulated islets: actual prospectives on progress and challenges," Advanced Drug Delivery Reviews, vol. 67-68, pp. 84-92, 2014.

[93] S. V. Hegarty, G. W. O’Keeffe, and A. M. Sullivan, "Neurotrophic factors: from neurodevelopmental regulators to novel therapies for Parkinson's disease," Neural Regeneration Research, vol. 9, no. 19, pp. 1708-1711, 2014.

[94] K. E. Haugstad, A. G. Håti, C. T. Nordgård et al., "Direct determination of chitosan-mucin interactions using a singlemolecule strategy: comparison to alginate-mucin interactions," Polymers, vol. 7, no. 2, pp. 161-185, 2015.

[95] G. Mythri, K. Kavitha, M. R. Kumar, and S. D. Jagadeesh Singh, "Novel mucoadhesive polymers-a review," Journal of Applied Pharmaceutical Science, vol. 1, no. 8, pp. 37-42, 2011.

[96] C. Taylor, J. P. Pearson, K. I. Draget, P. W. Dettmar, and O. Smidsrød, "Rheological characterisation of mixed gels of mucin and alginate," Carbohydrate Polymers, vol. 59, no. 2, pp. 189-195, 2005.

[97] F. Laffleur, "Mucoadhesive polymers for buccal drug delivery," Drug Development and Industrial Pharmacy, vol. 40, no. 5, pp. 591-598, 2014.

[98] C. Juliano, E. Gavini, M. Cossu, M. C. Bonferoni, and P. Giunchedi, "Mucoadhesive alginate matrices containing sodium carboxymethyl starch for buccal delivery: in vitro and in vivo studies," Journal of Drug Delivery Science and Technology, vol. 14, no. 2, pp. 159-163, 2004.

[99] M. J. Martín, A. C. Calpena, F. Fernández, M. Mallandrich, P. Gálvez, and B. Clares, "Development of alginate microspheres as nystatin carriers for oral mucosa drug delivery," Carbohydrate Polymers, vol. 117, pp. 140-149, 2015. 
[100] S. Haque, S. Md, J. K. Sahni, J. Ali, and S. Baboota, "Development and evaluation of brain targeted intranasal alginate nanoparticles for treatment of depression," Journal of Psychiatric Research, vol. 48, no. 1, pp. 1-12, 2014.

[101] R. J. Garmise, H. F. Staats, and A. J. Hickey, "Novel dry powder preparations of whole inactivated influenza virus for nasal vaccination," AAPS PharmSciTech, vol. 8, no. 4, pp. 2-10, 2007.

[102] J. R. Costa, N. C. Silva, B. Sarmento, and M. Pintado, "Potential chitosan-coated alginate nanoparticles for ocular delivery of daptomycin," European Journal of Clinical Microbiology \& Infectious Diseases, vol. 34, no. 6, pp. 1255-1262, 2015.

[103] Y. O. Batyrbekov, D. Rakhimbaeva, K. Musabekov, and B. Zhubanov, "Alginate based microparticle drug delivery systems for the treatment of eye cancer," MRS Proceedings, vol. 1209, Article ID 1209-YY03-04, 2009.

[104] P. Diós, S. Nagy, S. Pál et al., "Preformulation studies and optimization of sodium alginate based floating drug delivery system for eradication of Helicobacter pylori," European Journal of Pharmaceutics and Biopharmaceutics, vol. 96, pp. 196-206, 2015.

[105] A. O. Adebisi, P. R. Laity, and B. R. Conway, "Formulation and evaluation of floating mucoadhesive alginate beads for targeting Helicobacter pylori," Journal of Pharmacy and Pharmacology, vol. 67, no. 4, pp. 511-524, 2015.

[106] M. Szekalska, M. Wróblewska, K. Sosnowska, and K. Winnicka, "Influence of sodium alginate on hypoglycemic activity of metformin hydrochloride in the microspheres obtained by the spray drying," International Journal of Polymer Science, vol. 2016, 12 pages, 2016.

[107] M. Szekalska, A. Amelian, and K. Winnicka, "Alginate microspheres obtained by the spray drying technique as mucoadhesive carriers of ranitidine," Acta Pharmaceutica, vol. 65, no. 1, pp. $15-27,2015$.

[108] M. Szekalska, K. Winnicka, A. Czajkowska-Kośnik, K. Sosnowska, and A. Amelian, "Evaluation of alginate microspheres with metronidazole obtained by the spray drying technique," Acta Poloniae Pharmaceutica-Drug Research, vol. 72, no. 3, pp. 569-578, 2015.

[109] M. J. Martín-Villena, F. Fernández-Campos, A. C. CalpenaCampmany, N. Bozal-de Febrer, M. A. Ruiz-Martínez, and B. Clares-Naveros, "Novel microparticulate systems for the vaginal delivery of nystatin: development and characterization," Carbohydrate Polymers, vol. 94, no. 1, pp. 1-11, 2013.

[110] A. Khare, K. Grover, P. Pawar, and I. Singh, "Mucoadhesive polymers for enhancing retention in ocular drug delivery: a critical review," Reviews of Adhesion and Adhesives, vol. 2, no. 4, pp. 467-502, 2014.

[111] P. Prinderre, C. Sauzet, and C. Fuxen, "Advances in gastro retentive drug-delivery systems," Expert Opinion on Drug Delivery, vol. 8, no. 9, pp. 1189-1203, 2011.

[112] A. A. Kharia and A. K. Singhai, "Screening of most effective variables for development of gastroretentive mucoadhesive nanoparticles by Taguchi design," ISRN Nanomaterials, vol. 2013, 8 pages, 2013.

[113] O. Borges, J. Tavares, A. de Sousa, G. Borchard, H. E. Junginger, and A. Cordeiro-da-Silva, "Evaluation of the immune response following a short oral vaccination schedule with hepatitis B antigen encapsulated into alginate-coated chitosan nanoparticles," European Journal of Pharmaceutical Sciences, vol. 32, no. 4-5, pp. 278-290, 2007.

[114] F. Sarei, N. M. Dounighi, H. Zolfagharian, P. Khaki, and S. M. Bidhendi, "Alginate nanoparticles as a promising adjuvant and vaccine delivery system," Indian Journal of Pharmaceutical Sciences, vol. 75, no. 4, pp. 442-449, 2013.

[115] P. Nyvall, E. Corre, C. Boisset et al., "Characterization of mannuronan C-5-epimerase genes from the brown alga Laminaria digitata," Plant Physiology, vol. 133, no. 2, pp. 726-735, 2003.

[116] C. Campa, S. Holtan, N. Nilsen, T. M. Bjerkan, B. T. Stokke, and G. Skjåk-Bræk, "Biochemical analysis of the processive mechanism for epimerization of alginate by mannuronan C-5 epimerase AlgE4," The Biochemical Journal, vol. 381, no. 1, pp. 155-164, 2004.

[117] J.-S. Yang, Y.-J. Xie, and W. He, "Research progress on chemical modification of alginate: a review," Carbohydrate Polymers, vol. 84, no. 1, pp. 33-39, 2011.

[118] S. N. Pawar and K. J. Edgar, "Alginate derivatization: a review of chemistry, properties and applications," Biomaterials, vol. 33, no. 11, pp. 3279-3305, 2012.

[119] T. W. Wong, "Alginate graft copolymers and alginate-coexcipient physical mixture in oral drug delivery," The Journal of Pharmacy and Pharmacology, vol. 63, no. 12, pp. 1497-1512, 2011.

[120] S. W. Hutcheson, H. Zhang, and M. Suvorov, "Carbohydrase systems of Saccharophagus degradans degrading marine complex polysaccharides," Marine Drugs, vol. 9, no. 4, pp. 645-665, 2011.

[121] E. Broderick, H. Lyons, T. Pembroke, H. Byrne, B. Murray, and M. Hall, "The characterisation of a novel, covalently modified, amphiphilic alginate derivative, which retains gelling and nontoxic properties," Journal of Colloid and Interface Science, vol. 298, no. 1, pp. 154-161, 2006.

[122] H.-R. Lin, K. C. Sung, and W.-J. Vong, "In situ gelling of alginate/Pluronic solutions for ophthalmic delivery of pilocarpine," Biomacromolecules, vol. 5, no. 6, pp. 2358-2365, 2004.

[123] G. Coşkun, E. Karaca, M. Ozyurtlu, S. Özbek, A. Yermezler, and I. Cavuşoğlu, "Histological evaluation of wound healing performance of electrospun poly(vinyl alcohol)/sodium alginate as wound dressing in vivo," Bio-Medical Materials and Engineering, vol. 24, no. 2, pp. 1527-1536, 2014.

[124] A. A. Chang, M. S. Reuther, K. K. Briggs et al., "In vivo implantation of tissue-engineered human nasal septal neocartilage constructs: a pilot study," Otolaryngology-Head and Neck Surgery, vol. 146, no. 1, pp. 46-52, 2012.

[125] S. Vériter, J. Mergen, R.-M. Goebbels et al., "In vivo selection of biocompatible alginates for islet encapsulation and subcutaneous transplantation," Tissue Engineering Part A, vol. 16, no. 5, pp. 1503-1513, 2010.

[126] A. Sosnik, "Alginate particles as platform for drug delivery by the oral route: state-of-the-art," ISRN Pharmaceutics, vol. 2014, Article ID 926157, 17 pages, 2014.

[127] Generally Recognized as Safe (Internet), "U.S. Food and Drug Administration," http://www.fda.gov/Food/IngredientsPackagingLabeling/GRAS/SCOGS/ucm260857.htm.

[128] M. Otterlei, K. Østgaard, G. Skjåk-Bræk, O. Smidsrød, P. SoonShiong, and T. Espevik, "Induction of cytokine production from human monocytes stimulated with alginate," The Journal of Immunotherapy, vol. 10, no. 4, pp. 286-291, 1991.

[129] M. Ménard, J. Dusseault, G. Langlois et al., "Role of protein contaminants in the immunogenicity of alginates," Journal of Biomedical Materials Research Part B: Applied Biomaterials, vol. 93, no. 2, pp. 333-340, 2010.

[130] M. Greco, C. A. Sáez, M. T. Brown, and M. B. Bitonti, "A simple and effective method for high quality co-extraction of genomic DNA and total RNA from low biomass Ectocarpus siliculosus, 
the model brown alga," PLoS ONE, vol. 9, no. 5, Article ID e96470, 2014.

[131] L. Corvaglia, C. Monari, S. Martini, A. Aceti, and G. Faldella, "Pharmacological therapy of gastroesophageal reflux in preterm infants," Gastroenterology Research and Practice, vol. 2013, Article ID 714564, 12 pages, 2013.

[132] F. C. Hampson, A. Farndale, V. Strugala, J. Sykes, I. G. Jolliffe, and P. W. Dettmar, "Alginate rafts and their characterisation," International Journal of Pharmaceutics, vol. 294, no. 1-2, pp. 137147, 2005.

[133] DrugBank Database (Internet), University of Alberta, Canada, http://www.drugbank.ca.

[134] K. G. Mandel, B. P. Daggy, D. A. Brodie, and H. I. Jacoby, "Review article: alginate-raft formulations in the treatment of heartburn and acid reflux," Alimentary Pharmacology \& Therapeutics, vol. 14, no. 6, pp. 669-690, 2000.

[135] N. Yavorska, "Sodium alginate-a potential tool for weight management: effect on subjective appetite, food intake, and glycemic and insulin regulation," Journal of Undergraduate Life Sciences, vol. 6, no. 1, pp. 66-69, 2012.

[136] J. A. Williams, C. S. Lai, H. Corwin et al., "Inclusion of guar gum and alginate into a crispy bar improves postprandial glycemia in human," The Journal of Nutrition, vol. 134, no. 4, pp. 886-889, 2004.

[137] B. W. Wolf, C.-S. Lai, M. S. Kipnes et al., "Glycemic and insulinemic responses of nondiabetic healthy adult subjects to an experimental acid-induced viscosity complex incorporated into a glucose beverage," Nutrition, vol. 18, no. 7-8, pp. 621-626, 2002.

[138] I. Torsdottir, M. Alpsten, G. Holm, A.-S. Sandberg, and J. Tolli, "A small dose of soluble alginate-fiber affects postprandial glycemia and gastric emptying in humans with diabetes," The Journal of Nutrition, vol. 121, no. 6, pp. 795-799, 1991.

[139] C. A. Tarling, K. Woods, R. Zhang et al., "The search for novel human pancreatic $\alpha$-amylase inhibitors: high-throughput screening of terrestrial and marine natural product extracts," ChemBioChem, vol. 9, no. 3, pp. 433-438, 2008.

[140] Y. Idota, Y. Kogure, T. Kato et al., "Cholesterol-lowering effect of calcium alginate in rats," Biological \& Pharmaceutical Bulletin, vol. 39, no. 1, pp. 62-67, 2016.

[141] J. R. Paxman, J. C. Richardson, P. W. Dettmar, and B. M. Corfe, "Alginate reduces the increased uptake of cholesterol and glucose in overweight male subjects: a pilot study," Nutrition Research, vol. 28, no. 8, pp. 501-505, 2008.

[142] Y. Kimura, K. Watanabe, and H. Okuda, "Effects of soluble sodium alginate on cholesterol excretion and glucose tolerance in rats," Journal of Ethnopharmacology, vol. 54, no. 1, pp. 47-54, 1996.

[143] M. Georg Jensen, C. Pedersen, M. Kristensen, G. Frost, and A. Astrup, "Review: efficacy of alginate supplementation in relation to appetite regulation and metabolic risk factors: evidence from animal and human studies," Obesity Reviews, vol. 14, no. 2, pp. 129-144, 2013.

[144] D. Houghton, M. D. Wilcox, P. I. Chater, I. A. Brownlee, C. J. Seal, and J. P. Pearson, "Biological activity of alginate and its effect on pancreatic lipase inhibition as a potential treatment for obesity," Food Hydrocolloids, vol. 49, pp. 18-24, 2015.

[145] D.-H. Ngo and S.-K. Kim, "Sulfated polysaccharides as bioactive agents from marine algae," International Journal of Biological Macromolecules, vol. 62, pp. 70-75, 2013.
[146] J.-B. Lee, A. Takeshita, K. Hayashi, and T. Hayashi, "Structures and antiviral activities of polysaccharides from Sargassum trichophyllum," Carbohydrate Polymers, vol. 86, no. 2, pp. 995999, 2011.

[147] G. L. Yan, Y. M. Guo, J. M. Yuan, D. Liu, and B. K. Zhang, "Sodium alginate oligosaccharides from brown algae inhibit Salmonella enteritidis colonization in broiler chickens," Poultry Science, vol. 90, no. 7, pp. 1441-1448, 2011.

[148] S. Benavides, R. Villalobos-Carvajal, and J. E. Reyes, "Physical, mechanical and antibacterial properties of alginate film: effect of the crosslinking degree and oregano essential oil concentration," Journal of Food Engineering, vol. 110, no. 2, pp. 232-239, 2012.

[149] E.-W. Son, D.-K. Rhee, and S. Pyo, "Antiviral and tumoricidal activities of alginate-stimulated macrophages are mediated by different mechanisms," Archives of Pharmacal Research, vol. 26, no. 11, pp. 960-966, 2003.

[150] A. Ahmadi, S. Z. Moghadamtousi, S. Abubakar, and K. Zandi, "Antiviral potential of algae polysaccharides isolated from marine sources: a review," BioMed Research International, vol. 2015, Article ID 825203, 10 pages, 2015.

[151] S.-X. Wang, X.-S. Zhang, H.-S. Guan, and W. Wang, "Potential anti-HPV and related cancer agents from marine resources: an overview," Marine Drugs, vol. 12, no. 4, pp. 2019-2035, 2014.

[152] Y. Sano, "Antiviral activity of alginate against infection by tobacco mosaic virus," Carbohydrate Polymers, vol. 38, no. 2, pp. 183-186, 1999.

[153] M. Witvrouw and E. De Clercq, "Sulfated polysaccharides extracted from sea algae as potential antiviral drugs," General Pharmacology, vol. 29, no. 4, pp. 497-511, 1997.

[154] G. Meiyu, L. Fuchuan, X. Xianliang, L. Jing, Y. Zuowei, and G. Huashi, "The potential molecular targets of marine sulfated polymannuroguluronate interfering with HIV-1 entry. Interaction between SPMG and HIV-1 rgp120 and CD4 molecule," Antiviral Research, vol. 59, no. 2, pp. 127-135, 2003.

[155] E. H. Son, E. Y. Moon, D. K. Rhee, and S. Pyo, "Stimulation of various functions in murine peritoneal macrophages by high mannuronic acid-containing alginate (HMA) exposure in vivo," International Immunopharmacology, vol. 1, no. 1, pp. 147154, 2001.

[156] Z.-A. Yao, H.-G. Wu, B.-Q. Han, H.-M. Ma, Z.-F. Jiang, and Y.$\mathrm{G}$. Du, "The antithrombotic action of propylene glycol mannite sulfate (PGMS)," Pharmacological Research, vol. 53, no. 2, pp. 166-170, 2006.

[157] A. K. Taşkın, M. Yaşar, I. Ozaydın et al., "The hemostatic effect of calcium alginate in experimental splenic injury model," Turkish Journal of Trauma \& Emergency Surgery, vol. 19, no. 3, pp. 195199, 2013.

[158] H. Hattori, Y. Amano, Y. Nogami, B. Takase, and M. Ishihara, "Hemostasis for severe hemorrhage with photocrosslinkable chitosan hydrogel and calcium alginate," Annals of Biomedical Engineering, vol. 38, no. 12, pp. 3724-3732, 2010.

[159] K. Kaneda, S. Kuroda, N. Goto, D. Sato, K. I. Ohya, and S. Kasugai, "Is sodium alginate an alternative hemostatic material in the tooth extraction socket?" Journal of Oral Tissue Engineering, vol. 5, no. 3, pp. 127-133, 2007.

[160] Y. Zeng, D. Yang, P. Qiu et al., "Efficacy of Heparinoid PSS in treating cardiovascular diseases and beyond-a review of 27 years clinical experiences in China," Clinical and Applied Thrombosis/Hemostasis, vol. 22, no. 3, pp. 222-229, 2016.

[161] Y.-Y. Chen, W. Ji, J.-R. Du et al., "Preventive effects of low molecular mass potassium alginate extracted from brown algae 
on DOCA salt-induced hypertension in rats," Biomedicine \& Pharmacotherapy, vol. 64, no. 4, pp. 291-295, 2010.

[162] M. C. Rocha De Souza, C. T. Marques, C. M. Guerra Dore, F. R. Ferreira Da Silva, H. A. Oliveira Rocha, and E. L. Leite, "Antioxidant activities of sulfated polysaccharides from brown and red seaweeds," Journal of Applied Phycology, vol. 19, no. 2, pp. 153-160, 2007.

[163] F. Namvar, R. Mohamad, J. Baharara, S. Zafar-Balanejad, F. Fargahi, and H. S. Rahman, "Antioxidant, antiproliferative, and antiangiogenesis effects of polyphenol-rich seaweed (Sargassum muticum)," BioMed Research International, vol. 2013, Article ID 604787, 9 pages, 2013.

[164] Y. Yamamoto, M. Kurachi, K. Yamaguchi, and T. Oda, "Stimulation of multiple cytokine production in mice by alginate oligosaccharides following intraperitoneal administration," Carbohydrate Research, vol. 342, no. 8, pp. 1133-1137, 2007.

[165] T. I. Imbs, S. P. Ermakova, O. S. Malyarenko (Vishchuk), V. V. Isakov, and T. N. Zvyagintseva, "Structural elucidation of polysaccharide fractions from the brown alga Coccophora langsdorfii and in vitro investigation of their anticancer activity," Carbohydrate Polymers, vol. 135, pp. 162-168, 2016.

[166] D. Maciel, P. Figueira, S. Xiao et al., "Redox-responsive alginate nanogels with enhanced anticancer cytotoxicity," Biomacromolecules, vol. 14, no. 9, pp. 3140-3146, 2013.

[167] H.-J. Jeong, S.-A. Lee, P.-D. Moon et al., "Alginic acid has anti-anaphylactic effects and inhibits inflammatory cytokine expression via suppression of nuclear factor- $\kappa$ B activation," Clinical and Experimental Allergy, vol. 36, no. 6, pp. 785-794, 2006.

[168] T. Uno, M. Hattori, and T. Yoshida, "Oral administration of alginic acid oligosaccharide suppresses IgE production and inhibits the induction of oral tolerance," Bioscience, Biotechnology and Biochemistry, vol. 70, no. 12, pp. 3054-3057, 2006.

[169] A. B. A. Ahmed, M. Adel, P. Karimi, and M. Peidayesh, "Chapter ten-pharmaceutical, cosmeceutical, and traditional applications of marine carbohydrates," Advances in Food and Nutrition Research, vol. 73, pp. 197-220, 2014.

[170] T. Andersen, C. Markussen, M. Dornish et al., "In situ gelation for cell immobilization and culture in alginate foam scaffolds," Tissue Engineering Part A, vol. 20, no. 3-4, pp. 600-610, 2014.

[171] H. Geckil, F. Xu, X. Zhang, S. Moon, and U. Demirci, "Engineering hydrogels as extracellular matrix mimics," Nanomedicine, vol. 5, no. 3, pp. 469-484, 2010.

[172] C. Godugu and M. Singh, "AlgiMatrix ${ }^{\mathrm{TM}}$-based 3D cell culture system as an in vitro tumor model: an important tool in cancer research," in Cancer Chemoprevention, vol. 1379 of Methods in Molecular Biology, pp. 117-128, Springer, 2016.

[173] T. Andersen, P. Auk-Emblem, and M. Dornish, "3D cell culture in alginate hydrogels," Microarrays, vol. 4, no. 2, pp. 133-161, 2015.

[174] C. Godugu, A. R. Patel, U. Desai, T. Andey, A. Sams, and M. Singh, "AlgiMatrix ${ }^{\mathrm{TM}}$ based $3 \mathrm{D}$ cell culture system as an in-vitro tumor model for anticancer studies," PLoS ONE, vol. 8, no. 1, Article ID e53708, 2013.

[175] S. J. M. Skinner, M. S. Geaney, H. Lin et al., "Encapsulated living choroid plexus cells: potential long-term treatments for central nervous system disease and trauma," Journal of Neural Engineering, vol. 6, no. 6, Article ID 065001, 2009.

[176] L. N. Pettingill, A. K. Wise, M. S. Geaney, and R. K. Shepherd, "Enhanced auditory neuron survival following cell-based BDNF treatment in the deaf guinea pig," PLoS ONE, vol. 6, no. 4, Article ID e18733, 2011.
[177] H. K. Yang and K.-H. Yoon, "Current status of encapsulated islet transplantation," Journal of Diabetes and its Complications, vol. 29, no. 5, pp. 737-743, 2015.

[178] A. L. Hillberg, K. Kathirgamanathan, J. B. Lam, L. Y. Law, O. Garkavenko, and R. B. Elliott, "Improving alginate-polyL-ornithine-alginate capsule biocompatibility through genipin crosslinking," Journal of Biomedical Materials Research-Part B Applied Biomaterials, vol. 101, no. 2, pp. 258-268, 2013.

[179] M. Qi, "Transplantation of encapsulated pancreatic islets as a treatment for patients with type 1 diabetes mellitus," Advances in Medicine, vol. 2014, Article ID 429710, 15 pages, 2014.

[180] J. Schweicher, C. Nyitray, and T. A. Desai, "Membranes to achieve immunoprotection of transplanted islets," Frontiers in Bioscience, vol. 19, no. 1, pp. 49-76, 2014.

[181] Clinical trials (Internet), U.S. National Institutes of Health, https://clinicaltrials.gov/ct2/results?term=alginate $\&$ Search $=$ Search.

[182] S. Irving, L. Gillespie, R. Richardson, D. Rowe, J. B. Fallon, and A. K. Wise, "Electroacoustic stimulation: now and into the future," BioMed Research International, vol. 2014, Article ID 350504, 17 pages, 2014.

[183] European Parkinson's Disease Association (Internet), http:// www.epda.eu.com/en/news/news-archive/2016/06-07-lct/.

[184] L. C. Powell, A. Sowedan, S. Khan et al., "The effect of alginate oligosaccharides on the mechanical properties of Gramnegative biofilms," Biofouling, vol. 29, no. 4, pp. 413-421, 2013.

[185] W. Hengzhuang, Z. Song, O. Ciofu, E. Onsøyen, P. D. Rye, and N. Høiby, "OligoG CF-5/20 disruption of mucoid Pseudomonas aeruginosa biofilm in a murine lung infection model," Antimicrobial Agents and Chemotherapy, vol. 60, no. 5, pp. 2620-2626, 2016.

[186] A. Tøndervik, H. Sletta, G. Klinkenberg et al., "Alginate oligosaccharides inhibit fungal cell growth and potentiate the activity of antifungals against Candida and Aspergillus spp.", PLoS ONE, vol. 9, no. 11, Article ID el12518, 2014.

[187] S. Chaluvadi, A. T. Hotchkiss Jr., J. E. Call et al., "Protection of probiotic bacteria in a synbiotic matrix following aerobic storage at $4{ }^{\circ} \mathrm{C}$," Beneficial Microbes, vol. 3, no. 3, pp. 175-187, 2012 . 

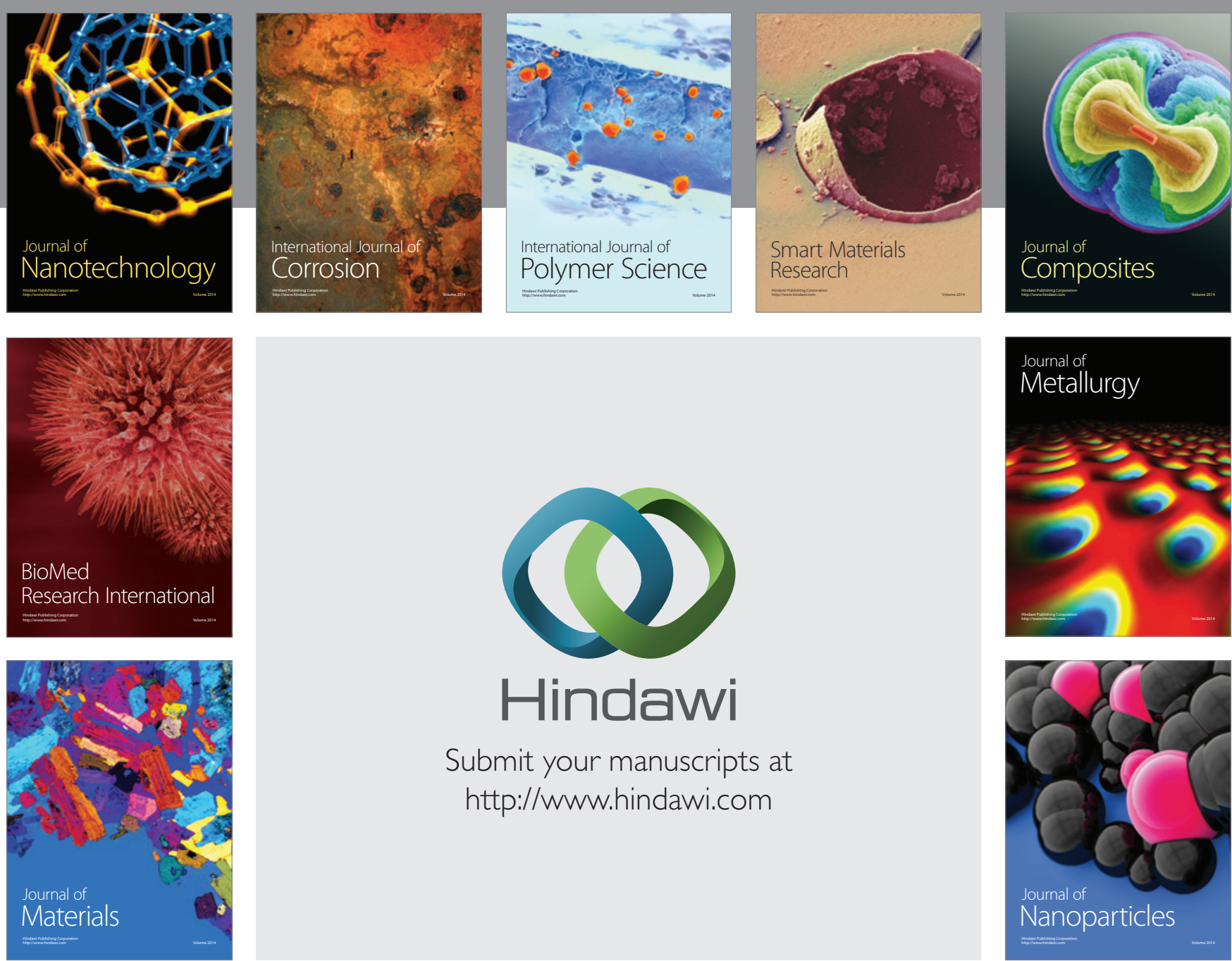

\section{Hindawi}

Submit your manuscripts at

http://www.hindawi.com

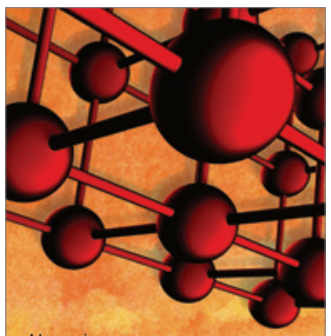

Materials Science and Engineering
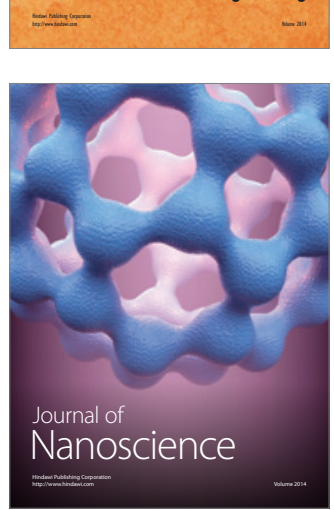
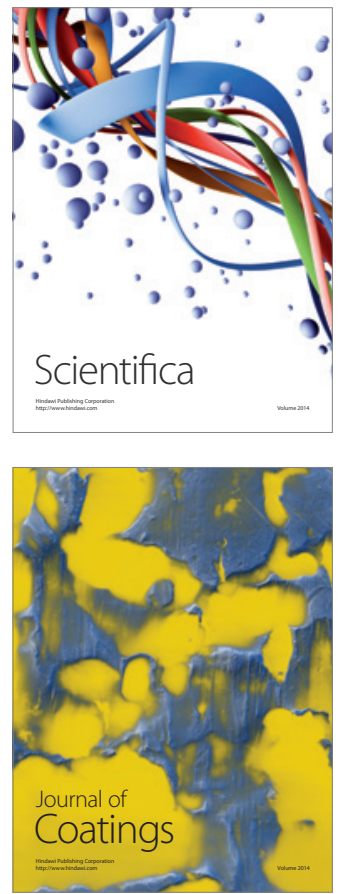
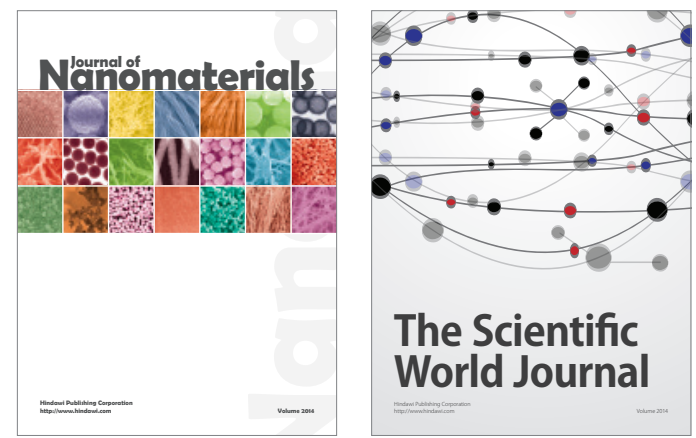

The Scientific World Journal
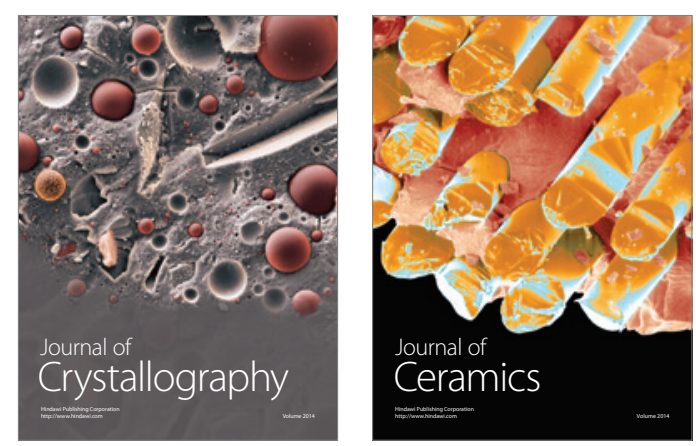
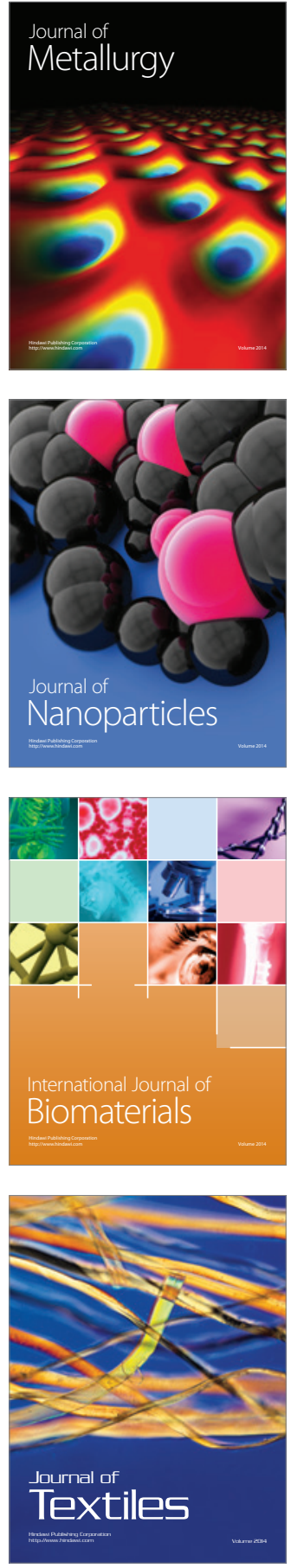